\title{
REDES FAMILIARES, CARRERAS ECLESIÁSTICAS Y EXTIRPACIÓN DE IDOLATRÍA. DOCTRINA DE CAMIÑA, TARAPACÁ. SIGLO XVII
}

\author{
FAMILY NETWORKS, ECCLESIASTICAL CAREERS, AND EXTIRPATION OF \\ IDOLATRY. PARISH OF CAMIÑA, TARAPACÁ, I7TH CENTURY
}

\author{
Jorge Hidalgo L. ${ }^{1}$, María Marsilli C. ${ }^{2}$ y Julio Aguilar H..$^{3,4}$
}

\begin{abstract}
La monarquía española expandió el catolicismo al Nuevo Mundo impulsando el adoctrinamiento de las poblaciones indígenas y la persecución de sus prácticas y creencias religiosas. Pieza fundamental de este proceso fue el clero local emplazado en las doctrinas indígenas, quienes con amplias facultades eclesiásticas y civiles mediaban entre el Estado, la Iglesia y la sociedad. Este artículo aborda los cambios en la vida social y religiosa andina a fines del siglo XVII en la doctrina de Camiña, ubicada en Tarapacá (Corregimiento de Arica, Obispado de Arequipa). El medio de observación es del estudio detallado de una bien organizada iniciativa de promoción eclesiástica protagonizada por una red clerical transatlántica que operaba tanto en el virreinato peruano como en España. Esta iniciativa se basaba en los lazos familiares de los doctrineros, así como en las alianzas entretejidas con caciques, hilacatas e indios principales. El estudio, análisis e interpretación de estas redes familiares y eclesiásticas hace inteligible el entorno social e histórico de las dinámicas que dieron vida a la religiosidad local. Posee el valor además de ser uno de los primeros estudios etnohistóricos sobre documentación alusiva a la extirpación de idolatría en el área de Tarapacá.
\end{abstract}

Palabras claves: extirpación de idolatrías, cristianización indígena colonial, curas, carreras eclesiásticas, redes familiares.

The Spanish monarchy spread Catholicism in the New World by promoting both the conversion of native peoples and persecuting their ancient religious practices and beliefs. Local clergy at work in Indian parishes (who held a vast array of civil and ecclesiastical powers and, therefore, became mediators between Church, State, and their social milieu) were crucial players in this process. This article elucidates a set of seventeenth-century social and ecclesiastical accommodations crafted by key players in the Camiña parish (Corregimiento de Arica, Diocese of Arequipa) reconstructed using the details of an ecclesiastical promotion initiative. Such an initiative relied, we demonstrate, upon a transatlantic power network with branches both in the Peruvian Viceroyalty and Spain. The socio/political/ecclesiastical tapestry thus elucidated was built using local parish priests' family networks and the alliances they crafted with native chiefs, hilacatas, and prominent Indians. A clear view of these power networks provides scholars with the appropriate context to discern the socio-historical dynamics that better explain the nature of local, daily religious practices. Finally, this study has the merit of offering a pioneering ethnohistorical analysis of the process of extirpation of idolatry in Tarapacá.

Key words: Extirpation of idolatry, Colonial native conversion to Catholicism, priests, ecclesiastical careers, family networks.

La monarquía Habsburga tuvo en la Iglesia católica un pilar fundamental para sostener el gobierno de los virreinatos americanos entre los siglos XVI y la primera mitad del XVIII (Brading 1991). En distintos niveles de la jerarquía eclesiástica (desde el alto clero hasta curas ubicados en beneficios rurales), los miembros de la Iglesia conservaron amplias facultades. Estos agentes del catolicismo no solamente tenían obligaciones pastorales, sino también civiles, administrativas y de vigilancia del orden moral y público. El poder de los curas párrocos se basaba en una tenue separación entre la vida religiosa y secular, el mismo principio que será eventualmente cuestionado por el asedio borbónico a los privilegios y funciones de la Iglesia colonial hacia la segunda mitad del siglo XVIII (Lynch 2012; Taylor 1996;). Hasta la primera mitad del siglo XVIII, el clero constituía un núcleo fundamental de autoridad: los curas eran representantes de la religión del Estado, intermediarios con fundamental autoridad entre lo profano y lo sagrado, ya que mediaban entre la feligresía y las autoridades civiles y eclesiásticas ${ }^{1}$.

\footnotetext{
Departamento de Ciencias Históricas, Universidad de Chile, Santiago, Chile. jorgehidalgolehuede@gmail.com

Department of History, John Carroll University. Cleveland, Estados Unidos. mmarsilli@ jcu.edu

Department of History, University of California, Davis, Estados Unidos. julaguilar@ucdavis.edu

4 Centro de Estudios Históricos, Universidad Bernardo O’Higgins, Santiago, Chile.
}

Recibido: marzo 2015. Aceptado: junio 2016.

http://dx.doi.org/10.4067/S0717-73562016005000026. Publicado en línea: 11-agosto-2016. 
Sabemos que curas doctrineros emplazados en parroquias rurales del virreinato peruano conservaron una destacada posición al interior de comunidades y pueblos durante la administración Habsburga. Tareas pastorales, como la enseñanza de la doctrina y la administración de los sacramentos, así como las campañas antiidolátricas de la segunda década del siglo XVII, les permitieron ejercer cierto control, aun cuando cuestionado, sobre las poblaciones andinas. Frecuentemente los feligreses indígenas acusaban a sus párrocos de codicia y mercantilismo (Lohmann 2001:400-403). Sabemos que en las doctrinas indígenas los párrocos podían tener un acceso privilegiado a indios de servicio, mano de obra y tierras, siempre y cuando lograran imponerse a otros poderes locales, como corregidores y caciques (O'Phelan 1978; Saignes 1991). Durante los siglos XVI y XVII la Corona, Virreyes y Audiencias debatieron sobre modos más efectivos de controlar las parroquias indígenas, lugares donde curas y corregidores sistemáticamente abusaban de la población andina. Si bien la legislación colonial buscó una política de contrapesos y de vigilancia recíproca entre corregidores y doctrineros, en algunas doctrinas corregidores y curas lograron entretejer alianzas para explotar la mano de obra indígena. Hacia fines del siglo XVII se vivió una particular tensión entre las autoridades civiles virreinales y provinciales y la Iglesia colonial. El duque La Palata despachó en 1684 una provisión que facultaba a los corregidores para iniciar informaciones secretas destinadas a verificar la obediencia eclesiástica a las disposiciones civiles y canónicas, así como los derechos a obvenciones. Tal disposición despertó el rechazo del Arzobispo de Lima, Liñan y Cisnero, quien, contando con el apoyo de Obispos como el de Arequipa y Quito, protestó con fundamentos canónicos y jurídicos la ofensa a la inmunidad eclesiástica que resultaba de tales atributos conferidos a funcionarios seculares (Lohmann 2001).

Lo cierto es que Obispos, miembros de los cabildos catedralicios y curas de parroquias vivían en un entramado de relaciones de sociabilidad que incluían a sus próximos o colaboradores en el oficio religioso, la familia nuclear y extensa (Irrigoyen 2008). El antiguo régimen colonial hispanoamericano poseía como principio básico de organización social a la familia barroca de naturaleza patriarcal. Como miembros de sus familias, los sacerdotes estaban unidos por lazos y obligaciones recíprocas con sus parientes y debían respetar tal jerarquía doméstica.
Debían además acudir en la administración y extensión del patrimonio del grupo y preservar la posición de la familia en el universo social (Lockhart y Schwartz 1983). Por tanto, no resulta extraño que muchas doctrinas funcionaran como verdaderas empresas familiares que, aprovechándose del trabajo y recursos indígenas, lograron monopolizar la producción de bienes de consumo para beneficiarse de las demandas del mercado interno colonial (Acosta 1982; Lavallé 1982).

Tanto la evangelización cotidiana de los nativos como las campañas contra la idolatría indígena se desarrollaron entonces en complejos contextos de interacción social, redes familiares y enmarañados lazos sociales. Durante estos procesos los sacerdotes y sus feligreses indígenas no fueron entidades aisladas ni discretas. Este trabajo analiza los cambios en la vida social y religiosa andina a fines del siglo XVII en la doctrina de Camiña, Obispado de Arequipa, a través del estudio detallado de una bien organizada iniciativa de promoción eclesiástica. Tal iniciativa se fundaba en una red clerical transatlántica que tenía bases tanto en el virreinato sur peruano como en España. El éxito de la petición dependía tanto de los lazos familiares de los doctrineros como de las alianzas entretejidas con caciques, hilacatas e indios principales. El estudio de estas redes familiares y eclesiásticas hace inteligible el entorno social e histórico de las dinámicas que dieron sustento material a la religiosidad local en los Andes coloniales. Posee el valor además de ser uno de los primeros estudios etnohistóricos con evidencias documentales que aluden a los procesos de extirpación de idolatría en el área de Tarapacá2

\section{La Doctrina de Camiña, Tenientazgo de Tarapacá. Siglo XVII}

El Corregimiento de Arica abarcaba un extenso territorio que comprendía el Tenientazgo de Tarapacá, un zona desértica de la vertiente occidental del sur Andes entre la quebrada de Camarones y el río Loa, conformado por una serie de pueblos y asentamientos de indios en su mayoría de origen aimara ${ }^{3}$. Inicialmente el adoctrinamiento religioso de las poblaciones indígenas de Tarapacá dependió de la encomienda ${ }^{4}$. Hasta 1613 Arica (y consecuentemente Tarapacá) dependieron del Obispado del Cuzco y a partir de esa fecha del Obispado de Arequipa (Vargas 1954:104-105; Vial 1984:31). La doctrina de Tarapacá parece haber sido una sola jurisdicción eclesiástica 
hasta 1571, cuando se propone su división en dos "curazgos" (expresión del documento por doctrina/ parroquia) siguiendo como eje divisorio la quebrada de Tarapacá. Al norte de esta quebrada, una de las doctrinas quedaría integrada por asentamientos en distintos pisos ecológicos desde la costa hasta la sierra como Chiapa, Sotoca y Camiña, y los puertos de Camarones y Pisagua ${ }^{5}$. Esta fue la base geográfica y comunitaria de lo que posteriormente será conocido como la doctrina de Camiña.

Las primeras décadas del siglo XVII trajeron una paulatina estabilización de la Iglesia colonial (Barnadas 1990). En el sur del virreinato peruano esto se expresó con la creación del Obispado de Arequipa que abarcaba los territorios del Contisuyu de los Incas, incluyendo el Corregimiento de Arica y el Tenientazgo de Tarapacá (Vial 1984), que recién en 1768 se transformará en Corregimiento 6 . Entre otros factores, la creación de esta nueva diócesis obedeció al clamor de la sociedad arequipeña de desvincularse del Obispado del Cusco, mejorar el servicio religioso y crear puestos para los curas provenientes de familias locales (Marsilli 2004; 2014). Después de la violenta erupción del volcán Huayna Putina en el año 1600, la elite criolla arequipeña, conocida con el nombre colectivo de "heredados" y cuya riqueza se basaba en la producción agrícola, debió diversificar sus actividades a fin de garantizar su sobrevivencia en una economía crecientemente competitiva (Davies 1984). La creación de una nueva jurisdicción eclesiástica ofreció a estas elites la oportunidad para extender sus negocios y poder, ubicando estratégicamente a miembros de sus redes familiares en diversos oficios del nuevo Obispado, donde pudieran apoyar sus actividades.

La creación del Obispado de Arequipa también reafirmó la autoridad episcopal y la superioridad del clero secular sobre las órdenes mendicantes, siguiendo así los dictámenes del Concilio de Trento. De sus 58 doctrinas, 40 fueron servidas por el clero secular. En la provincia de Tarapacá, una de las doctrinas era la que incluía en primer lugar a Camiña seguida por los pueblos de Sibaya, Husmagama, Chiapa, Sotoca y Estagama a cargo de un cura secular, según los autos de la división del Obispado de Arequipa de 16147. Sabemos que las doctrinas de Tarapacá estaban entre las más codiciadas por curas doctrineros. A inicios del siglo XVII, por ejemplo, Tarapacá pagaba el sínodo más alto de todo el Obispado (700 pesos) (Marsilli 2014:72-73). Los beneficios de servir en una doctrina rica, no obstante, aumentaban también el control que las autoridades eclesiásticas trataban de mantener sobre el clero.

Las autoridades episcopales ejercieron control en las distintas parroquias tarapaqueñas mediante las consuetudinarias visitas obispales (Hidalgo et al. 2014 [1985]). Por ejemplo, sabemos producto de una inspección realizada al cura de Camiña Diego Gonzáles Buitrón, por el Visitador General del Obispado don Juan Valverde en 1632 que la doctrina de Camiña estaba formada por la cabecera de Santo Tomás de Camiña, el principal pueblo de reducción y tres anexos (los pueblos de Santa María Magdalena de Chiapa, San Nicolás de Sibaya y Sotoca) (Figura $1)^{8}$. Hacia 1681 la doctrina estaba conformada por 14 iglesias nucleadas por el pueblo cabecera de Camiña y los tres anexos. Feligreses de la doctrina habitaban diferentes pueblos y quebradas, estrategia que les permitía cultivar con éxito, dada la escasez de tierras cultivables y agua ${ }^{9}$.

\section{Redes Eclesiásticas y Familiares}

Aun cuando exitosa económicamente, la relativa dispersión de los indios de la doctrina de Camiña era una dificultad para su correcta evangelización hacia fines del siglo XVII. El caso del cura propietario del beneficio Juan de Buitrón y Muxica, quien conservó este privilegio durante gran parte de la segunda mitad del siglo XVII, así lo demuestra ${ }^{10}$. Hacia 1681 este sacerdote se hallaba postrado enfermo del mal de la gota, posiblemente una artritis, de la que hasta el Obispo estaba enterado ${ }^{11}$. Se encontraba, por tanto, físicamente inhabilitado para administrar su parroquia y ejercer además otro cargo eclesiástico, el de vicario foráneo de Tarapacá, título que lo hacía responsable de vigilar y corregir amancebamientos, blasfemias, usuras y pecados públicos ${ }^{12}$. Para revertir esta situación, Buitrón y Muxica contó con dos clérigos asistentes durante la segunda mitad del siglo XVII: Martín de Moscoso y Buitrón y Simón Vernal Gutiérrez de Mendoza. Ambos curas emprendieron una planificada iniciativa para ascender en su posición dentro de la Iglesia movilizando para ello sus conexiones familiares y eclesiásticas.

El principal promotor de este intento de promoción eclesiástica fue el licenciado Martín de Moscoso y Buitrón, sobrino del enfermo cura propio de Camiña. En realidad, no era la primera vez que un cura apellidado Buitrón sirviera en esta doctrina. 


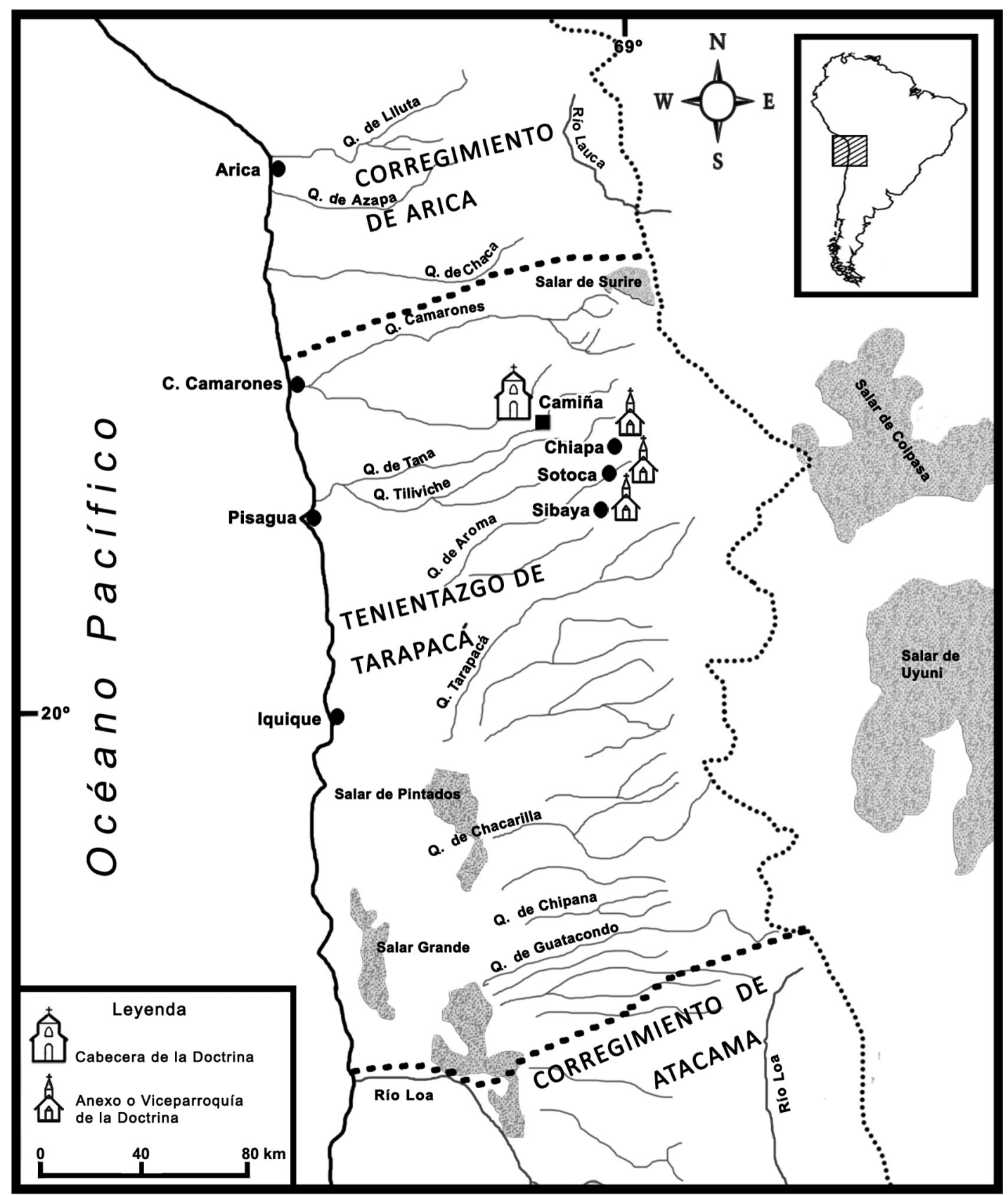

Figura 1. Mapa de la Doctrina de Camiña y sus anexos, siglo XVII.

Map of the Camiña parish and its anexos, $17^{\text {th }}$ century.

En cambio, sí era novedad que dos sacerdotes de una misma familia, tío y sobrino, coincidieran en Camiña en un mismo período ${ }^{13}$. Resulta probable que esto no fuera una simple coincidencia y que en el marco de una lógica de reciprocidad familiar, el sobrino ayudaba a su malogrado tío a cambio de estipendio, guía y protección.
Martín de Moscoso y Buitrón procedía de una connotada familia criolla de Arequipa. Su padre, Juan Santiago de Moscoso, era originario de Andalucía, había ocupado diversos cargos como protector de naturales, juez de censo, administrador de tierras, obrero mayor de la catedral, entre otros. Además, forjó amistad con Pedro de Villagómez, quien fuera 
Obispo de Arequipa (1631-1640). Su madre María de Buitrón y Mujica era una criolla descendiente de un conquistador y fundador de Arequipa. Tenía cinco hermanos entre los que se contaba un alcalde ordinario, un cura y tres hermanas casadas con distinguidos vecinos ${ }^{14}$.

En 1581, 1657 y 1677, por distintas razones, antepasados y miembros de la familia Moscoso y Buitrón se preocuparon de documentar la lealtad de la familia para con el Rey y la Iglesia, luego de servir en diversos y altos cargos civiles y eclesiásticos en Arequipa ${ }^{15}$. Emerge de esta documentación la imagen de una familia ansiosa por forjar una reputación noble y heroica a partir de la figura casi mítica del primer patriarca del linaje que pisó suelo americano. Se trataba del Capitán Gómez de León conquistador, hombre principal y caballero que combatió contra los indios que asediaron el Cusco, Diego de Almagro y la rebelión de Pizarro. Fue factor del Rey en la encomienda de Chucuito, además de fundador y encomendero en Arequipa. En todas estas acciones ofreció su fortuna proporcionando armas, caballos y esclavos. Prominentes miembros de la elite arequipeña acreditaron hacia 1677 que desde Gómez de León hasta la última generación del linaje, los Moscoso y Buitrón eran virtuosos, nobles, hidalgos y cristianos viejos ${ }^{16}$.

La noble familia del cura ayudante de Camiña poseía íntimas conexiones con la Iglesia colonial. Además de su tío, poseía una tía monja y un hermano que estudió bachillerato en artes y teología en la Universidad de San Marcos de Lima y servía hacia 1677 en el asiento minero de Caylloma ${ }^{17}$. La familia seguramente influyó en la decisión de Martín de Moscoso y Buitrón de abrazar el estado eclesiástico. Para acceder a las sagradas órdenes, el cura de Camiña seguramente hizo uso de su prominente origen social como miembro de una familia descendiente de conquistador además de su fortuna. Algunas informaciones lo ubican estudiando en el Colegio de San Bernardo en el Cusco (Echeverría 1952 [1804]:258). Sabemos también que su ordenación sacerdotal se efectuó entre 1668 y 1669 , por lo que se presume estuvo viviendo y educándose en el Cuzco gran parte de la década de 1660. Regentado por los jesuitas, el Colegio de San Bernardo recibía principalmente a estudiantes procedentes de familias acaudaladas no originarias del Cuzco. Aquellos con más de cincos años en el colegio podían optar a grados de bachiller, maestro, licenciado y doctor, otorgados por la Universidad de San Ignacio de Loyola, esenciales para las carreras civiles y eclesiásticas (Guibovich 2006) ${ }^{18}$. En estas instancias formativas, los sacerdotes forjaban contactos y amistades claves en sus futuras redes eclesiásticas (Taylor 1996:125).

Apenas recibió la consagración sacerdotal, Martín de Moscoso y Buitrón fue destinado para servir en calidad de ayudante en Camiña por el Obispo fray Juan de Almoguera ${ }^{19}$. Hacia 1681 llevaba 12 años relevando a su tío en el manejo de la parroquia y también de las responsabilidades de vicario foráneo de Tarapacá. Durante este tiempo no pudo obtener un curato propio que le asegurara un mayor sínodo. Sabemos que no obstante logró movilizar sus contactos con el alto clero arequipeño para sumar algunas distinciones. Por ejemplo, no queda duda que mantuvo una positiva relación con miembros del cabildo eclesiástico, ya que entre los testigos que reconocieron la pureza de sangre y méritos de su familia en 1677 se encontraban los licenciados y canónigos Esteban de Valencia y Diego de Vargas Machuca, prebendados de la Santa Catedral de Arequipa ${ }^{20}$. Más aún, el clérigo presbítero Antonio Buitrón y Muxica, otro pariente suyo, fue hacia 1657 rector de la catedral de Arequipa, visitador general del Obispado, además de cura en las parroquias de Quibe, Salamanca y Carumas ${ }^{21}$.

Probablemente los contactos con el alto clero arequipeño fueron clave para que el obispo Antonio de León apoyara la carrera eclesiástica de Martín de Moscoso y Buitrón. Los obispos que actuaban en América y Perú regularmente establecieron relaciones clientelares con el clero diocesano más cercano, de modo de contrarrestar la influencia y poder del clero regular (Guibovich 2006; Irrigoyen 2008). Antonio de León, quien tomó posesión del obispado en 1677, se caracterizó por una activa administración convocando un sínodo y manteniendo un acalorado debate con el virrey duque de $\mathrm{La}$ Palata respecto de la inmunidad que en materia de evangelización poseían los doctrineros frente a los corregidores como hemos reseñado anteriormente. En 1680, durante una de sus visitas al obispado, le entregó el título de Visitador de idolatría de toda la provincia de Tarapacá a Martín de Moscoso y Buitrón ${ }^{22}$. Las autoridades episcopales debían enviar periódicamente a la Corona una lista con los sacerdotes beneméritos (Irrigoyen 2008). Un segundo gesto del obispo fue precisamente incluir al cura asistente de Camiña entre las personas idóneas para ocupar dignidades y prelacías. Fue el único sacerdote 
de toda la provincia de Tarapacá considerado entre los meritorios para recibir alguna dignidad hacia julio de 1681. La autoridad episcopal argumentó que el licenciado poseía una gran constancia para servir el curato de Camiña considerando sus 24 leguas de distancia y el impedimento físico de su tío, y que además era “....persona noble y espera le honre a Vuestra Merced en premio de su trabajo"23.

Simón Vernal Gutiérrez, el otro cura asistente de Camiña, era un presbítero diocesano que hacia 1681 llevaba, según su informe de servicio, más de 12 años sirviendo en la parroquia ${ }^{24}$. Al igual que su compañero en la doctrina, Simón Vernal Gutiérrez descendía de una pía familia arequipeña cuyos integrantes ocupaban diversos puestos al interior de la Iglesia. Sus padres fueron Thomas Vernal Gutiérrez y Juana Arias Dávila, quienes tuvieron 11 hijos, seis de ellos varones que se habían educado y seguido carreras eclesiásticas en órdenes religiosas o seculares: Thomas fue clérigo presbítero y capellán del monasterio de monjas de Santa Catalina de Sena de Arequipa; fray Gerónimo religioso de la orden de San Francisco, predicador mayor y vicario de los conventos de Potosí y Chuquisaca; fray Juan de la misma orden y visitador del Convento de San Francisco de Arica; fray Gabriel también predicador franciscano; y fray Alonso religioso de la orden de Santo Domingo 25 .

Resulta claro que ambos sacerdotes asistentes pensaban que sus labores enseñando los misterios de la fe a los campesinos andinos de la doctrina de Camiña no habían sido propiamente recompensados. A fin de alcanzar tal reconocimiento, decidieron no escatimar esfuerzos para demostrar sus méritos a la Corona. Sus altas expectativas de recibir una promoción importante, como un curato propio o alguna prebenda en el cabildo eclesiástico, son ilustradas en el hecho que Martín de Moscoso y Buitrón viajó a los reinos de España para presentarse ante el monarca y sus consejos, según sostuvo “...para que se me premien estos servicios y otros que tengo que presentar de mis antepasados" ${ }^{26}$. En el mismo viaje debía presentar los servicios de su compañero en la doctrina Simón Vernal Gutiérrez, pues en un poder que este le entregó en Arica indicaba que lo confería “....expecialmente para que en mi nombre y representando mi persona pueda parecer ante el Rey nuestro señor que Dios guarde y ante sus Reales Consejos y chansillerias y demás tribunales o adonde me convenga y representando mis servicios pretenda el que su Magestad que Dios guarde me los premie"27. Cifradas esperanzas en alcanzar alguna promoción se puede desprender de un viaje de estas características que implicaba costos no menores, tramitar licencias y movilizar sus contactos al otro lado del Atlántico.

Lograr algún reconocimiento por parte de la Corona requería demostrar un origen noble, una instrucción sólida y méritos pastorales significativos, como la lucha contra la idolatría de los indios de Camiña, Sotoca, Chiapa y Sibaya. Por lo tanto, en primera instancia ambos sacerdotes debieron conseguir apoyos a nivel local y seguidamente obtener respaldo en la sede episcopal de Arequipa, donde debían movilizar sus influencias familiares al interior de la jerarquía eclesiástica.

Martín de Moscoso y Buitrón obtuvo una favorable recomendación del Deán y Cabildo de la Catedral de Arequipa. El Cabildo Eclesiástico señaló que este presbítero descendía de una familia noble y calificada, descendientes de conquistadores, y que por servir como cura ayudante de su tío no había tenido ocasión para presentarse a alguna oposición o concurso eclesiástico para obtener un curato propio. En virtud de su trabajo en Camiña y como visitador de idolatría de Tarapacá, el cabildo eclesiástico de Arequipa sugería al rey y al Consejo de Indias que Martín de Moscoso y Buitrón recibiera una prebenda en la Catedral de Arequipa. Además sería una promoción útil para que el clérigo de Camiña socorriera a su madre y hermanas, a las cuales describía como pobres, virtuosas y de calidad ${ }^{28}$. Entre los firmantes de esta recomendación se encontraba Antonio de Buitrón y Muxica, familiar y miembro del gobierno eclesiástico de la diócesis de Arequipa. Por otra parte, en Arequipa Simón Vernal Gutiérrez consiguió una certificación del Alcalde Ordinario de la ciudad que contaba con los testimonios de varios vecinos que acreditaron la calidad de su familia y además sus méritos en enseñar los misterios de la santa fe católica, predicar y explicar el evangelio a los indios de la parroquia de Camiña ${ }^{29}$.

Este intento de promoción eclesiástica descansaba en una urdida red compuesta por los propios clérigos, sus familias y contactos en la Iglesia de Arequipa y la sociedad colonial. Se basaba, por lo tanto, en una cuidadosa planificación y en el desarrollo de distintas estrategias. Ambos postulantes lograron elaborar y validar un relato que rescataba su rol en la evangelización indígena combinando sus orígenes sociales y subrayando, en uno de los casos, su nobleza americana. El viaje a España, además, 
manifiesta el mundo de lealtades y expectativas en que se movían los agentes coloniales. Pues en el mundo hispanoamericano del siglo XVII se esperaba que la lealtad a la familia y corporaciones fuera recompensada con favores, donde especialmente la suprema lealtad al monarca-padre despertaba constantemente esperanzas de mercedes y premios (Elliott 2009). Después de todo, no se trataba de una iniciativa movida únicamente por intereses individuales, sino también por la necesidad de asegurar el bienestar del conjunto de la familia de los sacerdotes y lograr las aspiraciones nacidas del afán de pertenecer a otra corporación, la Iglesia colonial. Dada lo ambicioso del proyecto, aun cuando ambos postulantes contaban con adecuados antecedentes y vínculos en Arequipa, debían además demostrar la opinión favorable de su feligresía. Una feligresía indígena que en el Virreinato de Perú era frecuentemente cuestionada por su resistencia a la evangelización y por recurrentes sospechas de practicar cultos idolátricos.

\section{Idolatrías y Cristianización}

Como hemos visto, los sacerdotes de Camiña desde sus orígenes formaban parte de una fuerte alianza social, familiar y regional que fue incrementada por su larga experiencia en la doctrina. Con todo, para hacerse merecedores de alguna merced también requerían de favorables testimonios a nivel local. El teniente de corregidor de Tarapacá, Nicolás Robles de Carvajal y su antecesor el capitán Pedro Muñoz de la Mata acreditaron hacia 1681 el buen desempeño del clero. Según sus testimonios, los doctrineros concurrían a los pueblos para administrar los sacramentos, especialmente las confesiones, y enseñar los fundamentos de la fe a los indios abarcando incluso en algunos momentos el vecino curato de San Lorenzo de Tarapacá ${ }^{30}$. Como hemos señalado, corregidores y tenientes tenían estrechas relaciones con los curas doctrineros debido a que administraban los mismos territorios y poblaciones, y, por lo tanto, estaban en condiciones de entregar eventualmente mutuos testimonios sobre sus conductas en buenos o malos términos, ya sea evidenciando conflictos o armonías, o prodigando alabanzas o vituperios ${ }^{31}$.

Además del respaldo de los funcionarios tarapaqueños, era esencial obtener una positiva declaración de los feligreses andinos, quienes avalarían los méritos evangelizadores y morales de los sacerdotes. Cualquier indicio de conflicto o acusación de los parroquianos indígenas podría afectar la reputación y el avance de la promoción eclesiástica de los clérigos. En la Diócesis de Arequipa las visitas eclesiásticas a las que periódicamente el clero fue sometido indican que los curas mayoritariamente procuraron mantener una relación no conflictiva con las elites nativas. En estas inspecciones, caciques y miembros del cabildo de indios se apresuraron en declarar los méritos evangelizadores y morales de sus sacerdotes ${ }^{32}$. Más adelante examinaremos la confiabilidad de este tipo de declaraciones.

Líderes indígenas del curato de Camiña desempeñaron un rol central en avalar la relación de servicios de los presbíteros Martín de Moscoso y Buitrón, y Simón Vernal Gutiérrez. Las declaraciones indígenas de la parroquia de Camiña fueron de carácter colectivo y no individual, a diferencia de los testimonios hispanos o criollos. Un conjunto de autoridades étnicas encarnaba el sentir de su respectivo pueblo; iniciaron las declaraciones los representantes del pueblo cabecera de la doctrina, es decir Camiña, seguidos por las autoridades de los otros tres pueblos anexos (Tabla 1). Lamentablemente carecemos de visitas o censos de este período para contrastar esta información, pero no creemos que existan razones para dudar de los cargos que se les atribuyen en los documentos que analizamos. Por otra parte, contamos con la visita eclesiástica a la doctrina en 1632 en donde aparece mencionada una estructura de autoridad muy similar ${ }^{33}$.

De cada uno de estos pueblos asistieron un curaca principal, segundas personas, hilacatas e indios principales siguiendo un régimen de autoridad indígena colonial fundada en el modelo toledano de comunidades de indios ${ }^{34}$. De acuerdo con las ordenanzas del Virrey Toledo, en los pueblos de indios los caciques, principales y otras autoridades exentas de tributos (cobradores, integrantes del cabildo indígena, ayudantes de la iglesia) formaron una jerarquía de gobierno indígena y de apoyo local a la doctrina, con atribuciones específicas, que estaban sujetos a la vez por corregidores y curas (Garrett 2005; Larson 1988; Platt et al. 2006). Todos los testigos se declararon como indios principales y naturales, lo que debemos entender en contraste con los indígenas del común, por lo que probablemente eran originarios de linajes prestigiosos dentro de las comunidades. Los curas doctrineros buscaron cultivar buenas relaciones con los caciques, entre otros motivos porque estos tenían que motivar 
Tabla 1. Autoridades indígenas de la Doctrina de Camiña, 1681. Indigenous authorities of the doctrine of Camiña, 1681.

\begin{tabular}{|c|c|c|c|c|}
\hline $\begin{array}{l}\text { Pueblo } \\
\text { Autoridad }\end{array}$ & Santo Tomás de Camiña & $\begin{array}{c}\text { Santa María Magdalena } \\
\text { de Chiapa }\end{array}$ & San Nicolás de Sibaya & Sotoca \\
\hline Curacas Principales & Alonso Valla & Juan Chuquichambi & Andrés Ilaja & Andrés Guacocama \\
\hline $\begin{array}{c}\text { Segundas personas } \\
\text { Hilacatas } \\
\text { Sacristán }\end{array}$ & $\begin{array}{c}\text { Andrés Caquisana } \\
\text { Juan Caquisana } \\
\text { Alonso Tala }\end{array}$ & Bartolomé Catamaya & Juan Guanca & Andrés [Laramja?] \\
\hline Principales & $\begin{array}{l}\text { Pedro Chambe / } \\
\text { Miguel Caqueo }\end{array}$ & $\begin{array}{c}\text { Diego Jachura/ } \\
\text { Balthasar Guayara/ } \\
\text { Juan [Chiriaya?] } \\
\text { García Chuquichambi }\end{array}$ & $\begin{array}{c}\text { Lorenzo Caques/ } \\
\text { Balthasar Tinta/ } \\
\text { Francisco Ylaja/ } \\
\text { Martín Taco }\end{array}$ & $\begin{array}{l}\text { Juan Caquena/ } \\
\text { Estevan Vilca/ } \\
\text { Pedro Carpa }\end{array}$ \\
\hline
\end{tabular}

Fuente: AGI, Lima, 264, N 17 (1), Informe de Méritos del Licenciado Martín de Moscoso y de Buitrón, cura asistente y vicario foráneo de la Doctrina de Camiña, 1681. Elaborado por los autores.

a sus indígenas a asistir a la doctrina y además facilitar el acceso a la mano de obra indígena según disposiciones del ordenamiento toledano (Marsilli 2004). El trabajo de los indios no solo era necesario en las actividades económicas del cura, sino también en la construcción o reconstrucción de iglesias, actividad recurrente en el obispado de Arequipa por los frecuentes terremotos (Marsilli 2002, 2014).

El pueblo de Camiña, cabecera de la doctrina, reunía la mayor cantidad de autoridades indígenas, incluido el único sacristán, individuo cercano al cura propietario, quien por ostentar dicha función se encontraba exento de pagar tributos y libre de servicios personales ${ }^{35}$. Los pueblos anexos de Chiapa, Sibaya y Sotoca, presentaron once indios principales, cuya condición denotaba prestigio y rango al interior de sus comunidades probablemente por los servicios prestados en el sistema de $\operatorname{cargos}^{36}$. La presencia de hilacatas, por otra parte, indica que se trataba de poblaciones de tradición aimara ${ }^{37}$.

Los parroquianos andinos necesitaron de intérpretes para manifestar el apoyo a sus curas doctrineros. Al finalizar sus testimonios no todas las autoridades indígenas fueron capaces de firmar, excepto Alonso Valla, curaca principal de Camiña, Pedro Chuquichambe, sacristán de Camiña, Juan Chuquichambe, curaca principal de Chiapa, y García Chuquichambe, indio principal de Chiapa. Dadas las responsabilidades de su cargo y proximidad de trato con grupos no indígenas, el cacique principal de la doctrina y el sacristán seguramente recibieron algún grado de preparación en lectura y escritura. Destacaba en este listado los indios apellidados Chuquichambe de Chiapa y Camiña quienes firmaron sus declaraciones. Tal particular indica un foco de enseñanza en este sector de Tarapacá y una temprana preocupación de este grupo familiar por la educación de sus descendientes, algo que es necesario indagar a la luz de esta pista. Resulta claro que las autoridades indígenas del tenientazgo de Tarapacá cultivaron una larga experiencia con la cultura legal colonial participando activamente en procesos judiciales y administrativos, ya sea vista con fines de elevar acusaciones para defender el acceso a sus bienes comunitarios y/o denunciar ante audiencias y visitadores eclesiásticos, abusos de doctrineros y corregidores (Hidalgo et al. 2014 [1985); Paz Soldán 1878). Los grupos andinos regionales a fines del siglo XVII conocían a cabalidad la importancia de visitas y procesos judiciales en que actuaban deliberativamente, comprendiendo el papel decisivo de sus testimonios para las aspiraciones de promoción eclesiástica de los párrocos.

En conjunto, los testimonios de las autoridades indígenas indicaron que los licenciados Martín de Moscoso y Buitrón y Simón Vernal Gutiérrez llegaron a la doctrina para salvarlos de su miseria espiritual y material. Los nativos añadieron que ambos curas emprendieron tal tarea en difíciles condiciones, dada la extensión de la doctrina, sus aldeas apartadas y caminos inaccesibles. Resulta interesante señalar que estas últimas expresiones parecen más propias de un discurso de un foráneo como un cura que de una población indígena originaria quienes seguramente veían como natural y hasta favorable la extensión y diversidad de su territorio comunitario.

Según el testimonio nativo, la salvación espiritual de los indios obedecía en primer lugar a la puntualidad con que ambos sacerdotes acudían en la administración de los santos sacramentos. De 
acuerdo con el testimonio del curaca y autoridades del pueblo de Chiapa, los curas no cobraban obvenciones por los sacramentos ${ }^{38}$. Testigos residentes en los diferentes pueblos subrayaron particularmente la importancia que el clero otorgaba a las confesiones anuales concurriendo, incluso, a confesar a indígenas que lo requerían de otras jurisdicciones. El curaca Alonso Valla junto a su segunda persona, hilacatas, sacristán e indios principales de Camiña además señalaron que los sacerdotes estaban permanentemente afanados en que los indios tuvieran un buen morir cristiano ${ }^{39}$.

La enseñanza de la doctrina también fue un elemento relevante en la salvación de las almas de los indios. De acuerdo con los testimonios del curaca de Sibaya Andrés Ilaja y otras autoridades indígenas de ese pueblo, los indios de la región eran gente bruta, pero que cambiaron positivamente gracias al adoctrinamiento dispensado por sus clérigos, concluyendo que "[h]oy con dicha enseñanza se hallan capases y saben los fundamentos de nuestra Santa fee Catholica" 40 . Este testimonio también refleja una apropiación del discurso de los sacerdotes asumiendo la existencia de un pasado pagano y un presente cristiano. Igualmente, los representantes del pueblo de Sotoca afirmaron que ellos y el resto de los indios del beneficio eran ahora capaces e instruidos en los misterios de la fe, en virtud del celo que los curas tuvieron de su instrucción ${ }^{41}$. Autoridades indígenas de Camiña indicaron que algunas veces incluso el clero azotaba a los indios que no acudían puntualmente a la enseñanza ${ }^{42}$. Aparentemente los miembros de la elite indígena no tenían problemas en aceptar que se castigara físicamente a los indios del común como parte normal de la administración de la parroquia (Taylor 1996:207). En la diócesis de Arequipa regularmente los caciques defendían a los curas si eran acusados de usar demasiada severidad, aunque la reacción no era la misma en caso de que ellos mismos fueran objetos de castigos (Marsilli 2004). Los líderes de Camiña observaron en su testimonio que los azotes eran un método evangelizador admisible, una muestra del celo e interés de los párrocos por su adoctrinamiento ${ }^{43}$.

Los curas ayudantes de la parroquia de Camiña también contribuyeron al bienestar de los indios desempeñando funciones curativas. Caciques y líderes andinos de todos los pueblos de la doctrina concordaron que la provincia había sufrido intensas pestes. Grupos indígenas de
Sibaya destacaron que los curas traían remedios a su costa y permanecían con ellos hasta que las pestes declinaban. Indios principales y caciques fueron enfáticos en señalar que las pestes no afectaban nunca a un único pueblo y que por lo que los curas se movilizaban por cada iglesia y anexo de la parroquia socorriendo con medicinas y dando la confesión a los campesinos enfermos que se encontraban en los umbrales de la muerte. Frecuentes en la zona andina a lo largo del siglo XVII, estas epidemias tuvieron aparentemente en vilo la vida de los pueblos tarapaqueños, coyuntura de crisis en que los curas habrían asumido un papel paralelo al curandero nativo o yatirit ${ }^{44}$.

Los líderes andinos de la doctrina calificaron a Martín de Moscoso y Buitrón y a Simón Vernal Gutiérrez como padres universales de todos los pobres feligreses indígenas, en virtud de la protección y caridad para salvar las almas y atender las necesidades que atravesaban. Esta aseveración de menores relativos fue ampliamente utilizada en el leguaje legal colonial, pero también pudo ser un discurso apropiado por los andinos para dirigirse a las autoridades superiores en orden a defenderse como desvalidos y necesitados de la protección ante abusos de terceros. El reiterado calificativo de "verdadero padre" con que los parroquianos andinos describieron a sus curas refleja una metáfora contenida en el lenguaje y práctica pastoral que familiarizaba la relación colonial (Dean 2002). De acuerdo con los testimonios, los indios, menores indefensos e ignorantes, hallaban en el párroco a un padre que los protegía de enfermedades, enseñaba los misterios de la fe y reprendía mediante castigos corporales las faltas a la doctrina.

Probablemente la importancia conferida a la salvación de los indios no quedó en ningún otro aspecto tan manifiesta como en la necesidad que estos abandonaran sus cultos originales. El verdadero estado de la conversión religiosa de los nativos andinos fue motivo de discusión al interior de la Iglesia y sociedad virreinal peruana a lo largo del siglo XVII. En los albores de aquel siglo imperó en el arzobispado de Lima la opinión que el avance de la temprana evangelización fue una ilusión tras revelarse que los indios seguían adorando a antiguos ídolos o falsos dioses y creyendo en supersticiones. Para ello se institucionalizaron las "campañas contra la idolatría indígena", un proceso eclesiástico de carácter judicial que concibió estos cultos nativos como delito y que contó con visitadores especiales 
para la pesquisa y destrucción de huacas (Cordero 2010; Duviols 1971). En contraste con el vigor que estas campañas alcanzaron en el arzobispado de Lima, en la diócesis de Arequipa los expedientes por idolatría fueron más bien escasos, primando relaciones de alianzas entre el clero y los grupos andinos (Marsilli 2012, 2014).

En el caso de la provincia de Tarapacá y la doctrina de Camiña existen en el siglo XVII escasos antecedentes documentales sobre cultos nativos idolátricos, como lo concebían y perseguían los agentes evangelizadores. En 1632, los indios de la doctrina de Camiña y sus tres anexos atestiguaron que conocían los fundamentos de la fe y que eran buenos cristianos ${ }^{45}$. Otros miembros del clero no compartían esta opinión. Sabemos que en 1636, en el marco de su visita al Corregimiento de Arica que incluía Tarapacá, el nuevo Obispo de Arequipa Pedro de Villagómez destruyó huacas y sepulcros donde supuestamente los indios practicaban supersticiones e idolatría (Hidalgo et al. 2014). Por otra parte, parroquias de la región contaron con sacerdotes especialistas en idolatrías andinas como el cura de Tarapacá Pedro de Porrasdana, quien hacia 1637 había sido visitador general de idolatría de la diócesis de Arequipa y examinador de la lengua de los naturales ${ }^{46}$.

Si bien el interés por erradicar la idolatría experimentó sus momentos más álgidos hacia 1620 en el arzobispado de Lima, la Iglesia y las autoridades virreinales no abandonaron del todo su inquietud por acabar con los cultos indígenas a lo largo del siglo XVII e inicios del siglo XVIII ${ }^{47}$. Por ejemplo, el Sínodo de Arequipa de 1684 declaró el desconsuelo de la Iglesia por el arraigo de la idolatría y la obstinación de los indios en mantener sus ritos y ceremonias. Por ello recomendó continuar las averiguaciones, visitas y procesos, e imponer a todos los curas la obligación de leer la instrucción contra las idolatrías compilada por Pedro de Villagómez. En caso que el cura párroco no lograra extirpar la influencia del demonio entre sus indios, el visitador de idolatría debía actuar con prontitud, ya que poseía amplias facultades para desarrollar procesos judiciales, prender reos y dictar sentencias en primera instancia ${ }^{48}$.

Hacia 1680 el Obispo de Arequipa Antonio de León estaba informado sobre la persistencia de idolatrías en su diócesis y la situación del partido de Tarapacá en especial, hecho que constató probablemente en algunas de las tres visitas que realizó al obispado ${ }^{49}$. Clandestinos y valiéndose de la sinuosidad del territorio tarapaqueño, normalmente de difícil acceso, los nativos seguían practicando sus antiguos cultos. Debido a sus múltiples obligaciones y las largas distancias, el obispo requería de apoyo especial para combatir la adoración a falsos dioses y supersticiones en Tarapacá. Estas razones llevaron a que nombrara a Martín de Moscoso y Buitrón, cura ayudante de Camiña, como visitador de idolatría de toda la provincia de Tarapacá. En ceremonia pública se entregaron las atribuciones al nuevo visitador, quien estaba autorizado a llevar causas, censurar, fulminar, reconciliar penitentes "...y castigar culpados con la blandura que requiere la incapacidad de las personas" 50 . Asimismo, se impuso como castigo la excomunión a cualquier persona, independiente de su condición, en caso de desobedecer al nuevo visitador de idolatría de Tarapacá.

Hacia 1681 el exteniente de Corregidor de Tarapacá Pedro Muñoz Rodríguez de la Mata relataba en su declaración que mientras visitaba los pueblos para impartir justicia observó al cura Martín de Moscoso y Buitrón administrando la parroquia y desempañándose como un celoso Visitador de Idolatría. En varias ocasiones tuvo noticia que el cura era muy diligente para hacer inquisición y pesquisa de si los indios de la provincia tenían algunas supersticiones con el objeto de extirparlas y castigarlas ${ }^{51}$. Los propios indígenas fueron más enfáticos en acreditar la labor extirpadora lograda en la región. Curacas e indios principales de Chiapa señalaron que el cura de Camiña realizaba recurrentes averiguaciones sobre la existencia de supersticiones e idolatrías. Por ejemplo, Don Andrés Guacocana, curaca principal de Sotoca, su segunda persona Don Andrés Laramja y los indios principales Juan Caquena, Esteban Vilca y Pedro Carpa concluyeron que ellos

...se ven libres de las superstiçiones y Ydolatrias pues con el mucho cuidadado [sic] que a puesto en estirparlas no se oye decir que en toda esta provincia aya quedado rastros ni señal de ella ${ }^{52}$.

La pretendida desaparición total de la idolatría nativa en Camiña puede a primera vista ser entendida como un triunfo innegable de la expansión católica en los Andes. El análisis etnohistórico, no obstante, como veremos en el siguiente apartado, nos pone en alerta sobre la simplificación de los cambios religiosos que estos documentos sugieren. 


\section{Detrás de las Declaraciones Indígenas Acciones Políticas e Interacciones en la Vida Parroquial}

La búsqueda de mejores posiciones o parroquias con superiores ingresos y más cercanas a ciudades y sedes episcopales impulsó a los sacerdotes a dejar testimonio de sus méritos y servicios. Algunos sacerdotes del virreinato peruano destacaron por sobre todo su lucha contra el demonio y las idolatrías nativas (Ramos 1992). Otros subrayaron sus labores pastorales y otros méritos como su descendencia legítima de padres españoles o criollos ilustres, cristianos viejos o proceder de los primeros conquistadores; tener logros académicos, doctores o licenciados; construir o reconstruir iglesias y dotarlas de ornamentos; obras de caridad dignas de memoria como cuidar de sus feligreses más pobres, ayudarlos en sus enfermedades con medicinas o en épocas de hambre; promover la devoción con cofradías, haber disminuido la embriaguez y el adulterio, etc. (Taylor 1996). La iniciativa de promoción eclesiástica de los curas de la doctrina de Camiña parece combinar ambas estrategias. Por una parte, tratar de probar que se ha tenido pleno éxito en la extirpación de idolatrías y por otra dar cuenta de la excelencia y dedicación como religiosos.

La documentación base del análisis propuesto corresponde a informes de testigos hispanos e indígenas conducentes a comprobar y dejar registro del buen servicio de los curas. Las declaraciones de terceros eran fundamentales en vista de exhibir un relato socialmente legitimado. Generalmente, las informaciones recogidas en estos informes eran utilizadas para la elaboración de una relación de mérito y servicio donde los actores coloniales podían demostrar su desempeño y virtudes individuales y familiares como hazañas, honor y pureza de sangre (Macleod 1998). Las elites indígenas tempranamente se interiorizaron de la relevancia de las probanzas o relaciones de servicio y méritos (Jurado 2014; Martínez 2014; Platt et al. 2006), mientras que los funcionarios americanos frecuentemente presentaban las suyas en el marco de una férrea competencia por conseguir algún ascenso en la burocracia y sociedad colonial, mas no pocas de estas relaciones fueron descartadas por contener exageraciones o faltas a la verdad (Macleod 1998 $)^{53}$. Respecto de esto último, si bien todos los testimonios, incluidos los hispanos o criollos, podían ser objetos de cuestionamientos, obispos y juristas del virreinato peruano del siglo XVI y XVII llamaron particularmente la atención sobre las debilidades de las declaraciones indígenas en procesos judiciales y administrativos. Pensaban que los andinos por ser nuevos en la fe eran más inclinados a perjurar y susceptibles de persuasiones por parte de jueces y otros interesados (Charles 2010). Por esta razón, se ha argumentado que los testimonios eran muchas veces fraguados de acuerdo con la voluntad de los párrocos y que sus testigos no podían sino confirmar lo que se les presionaba a declarar ${ }^{54}$.

En ese sentido, analizar esta información exige mantener una actitud cautelosa frente a la documentación como productos coloniales que favorecían los intereses de los curas. Esto nos lleva a insistir que estas probanzas se desarrollaron en un contexto de desiguales relaciones de poder y que en términos generales la opinión de los líderes indígenas parece responder a un guión previamente definido como parte de una orquestada acción del clero y sus familias por obtener un ascenso eclesiástico. De esto no podemos concluir que necesariamente los caciques, segundas personas, hilacatas, sacristanes indígenas y principales fueron meramente sujetos pasivos y manipulados. Antes bien, exige considerar las condiciones y posibilidades históricas de los actores locales que llevaron a que en tal coyuntura se sucediera el respaldo indígena a los sacerdotes. Desde esta última perspectiva, debemos entender las declaraciones indígenas de 1681 no como un hecho aislado fruto de una posible coerción, sino también como mediada por una larga interacción entre curas e indígenas en el marco de la vida parroquial. En ese contexto, tampoco se puede desconocer la secular experiencia y capacidad política de los caciques y líderes indígenas de la doctrina de Camiña para manejarse con los agentes pastorales y otras instituciones del gobierno colonial.

Difícilmente los caciques de Camiña y de los otros pueblos anexos desconocían las implicancias de su participación en una información de servicio de un funcionario colonial hacia 1681. Este sector de la sociedad indígena acumulaba largos años desenvolviéndose en el marco de las reglas del Estado colonial acudiendo a tribunales eclesiásticos y civiles. En 1620, los caciques del tenientazgo 
de Tarapacá acudieron ante la Audiencia de Lima para denunciar los abusos y apoderamiento de tierra y aguas por parte de un sacerdote. También aprovechaban las visitas de autoridades episcopales para acusar la explotación de los corregidores (Hidalgo et al. 2014). Antes de 1681 los caciques e indios principales poseían un innegable manejo político capaz de ser transmitido a sus sucesores, conocían la cultura escrita y judicial colonial y eran capaces de desplegar estrategias legales relacionándose convenientemente con autoridades superiores, escribanos, protectores e intérpretes.

Por otra parte, como se ha argumentado para el caso de la visita personal de indios (Guevara Gil y Salomon 1996), una información de servicio como la desarrollada en Camiña hacia 1681 era un complejo ritual político conformado por un conjunto de acciones implementadas antes y durante del interrogatorio. Vale decir, la participación indígena en las informaciones de servicio no se reducían a un único acto notarial eclesiástico en que sencillamente se inscribían las rúbricas de los testigos. Un ejemplo de ello sucedió en la visita eclesiástica de 1632 donde los caciques, hilacatas, segundas personas e indios principales de los cuatro pueblos principales de la doctrina de Camiña se congregaron en la quebrada de Tana para ofrecer sus declaraciones (Figura 1). La recopilación de los testimonios habría generado entonces un espacio de interacción para que los caciques discutieran y consensuaran su declaración frente al visitador eclesiástico. Algo similar ocurrió en 1681, ya que el registro documental describe que los representantes de cada uno de los pueblos también se reunieron para dar su testimonio. Además de esta congregación de los caciques y otros indios líderes de las comunidades, no hay que olvidar que antes de la ejecución del interrogatorio podrían haber circulado noticias previas sobre la relación de servicio por parte de los propios curas, generando expectativas y una toma de decisión respecto de las acciones a emprender por parte de los indígenas. La participación de los caciques en inspecciones o procedimientos administrativos y judiciales civiles o eclesiásticas les permitía además reafirmar su posición frente al Estado, la Iglesia y el común de indios donde los líderes indígenas también podían canalizar sus propias agendas.

Analizando la vida parroquial de Camiña previa a 1681 es posible advertir que los caciques e indios principales habían cultivado una indiscutible cercanía con la Iglesia colonial. En los registros parroquiales se aprecia la deferencia que los sacerdotes tuvieron hacia las autoridades étnicas y existen indicios sobre la mutua colaboración entre estos líderes y el clero, siendo usual que los indios principales de los pueblos colaboraran en las labores pastorales. Por ejemplo, el Licenciado Martín de Moscoso y Buitrón recibió la ayuda de los hilacatas Diego Cata Cata y Lorenzo Huyomayo y de dos indios sacristanes, Balthasar Tinta y Juan Jachura, para oficiar casamientos de originarios o forasteros en pueblos y ayllus de Mocha, Sotoca, Sibaya y Huaviña entre 1672-168055. Estos hilacatas y sacristanes fueron los testigos de fe que demandaba el protocolo parroquial y posiblemente eran garantía para los mismos contrayentes, sus familias y la comunidad. Cabe destacar que los sacristanes que actuaron en estos casamientos coinciden con los nombres de indios principales de Sibaya y Sotoca que juzgaron positivamente al clero de Camiña en $1681^{56}$. Lo importante a subrayar es que el despliegue de los rituales católicos significó una proximidad y/o complicidad entre el clero y los hilacatas y sacristanes. Otro caso similar de participación en ceremonias religiosas y asistencia al cura corresponde al curaca de Chiapa, quien fue el responsable de varios entierros o sepulturas eclesiásticas realizados en el templo del pueblo oficiado por el cura Simón Vernal Gutiérrez en 1681 y $1682^{57}$.

Otro teatro de observación del escenario social de la parroquia de Camiña se encuentra en las visitas de los Obispos de Arequipa, las cuales entregan valiosas evidencias de la relación que los caciques e indios principales mantenían con prelados y curas doctrineros. Las visitas de los Obispos o sus representantes a las parroquias indígenas son elocuentes de cómo los agentes pastorales y los feligreses indígenas interactuaban, negociaban y daban forma a la cultura política colonial, más allá de las dimensiones represivas o de resistencia indígena asociadas a estas inspecciones (Ramos 2016). Resulta posible constatar lo anterior en el caso de la visita a la doctrina de Camiña por el Obispo de Arequipa Antonio de León en septiembre de $1680^{58}$. En ella se aprecia el grado de cercanía tejida entre caciques, indios principales y la Iglesia colonial. En esa oportunidad el Obispo instruyó a los curas para mejorar el registro de las partidas de bautizos ${ }^{59}$. Durante su visita también tuvo ocasión 
de confirmar a feligreses indígenas, hispanos y esclavos negros de la doctrina y de Carangas ${ }^{60}$. Entre los cientos de registros de confirmaciones destacan los hijos de los caciques e indios principales, autoridades distinguidas en el registro parroquial con el título honorífico de "Don" y que un año más tarde atestiguaran a favor de Martín de Moscoso y Buitrón, y de Simón Vernal Gutiérrez ${ }^{61}$. En 1680 el Obispo confirmó a las hijas de Don Alonso Valla, curaca principal de Camiña, y los hijos de Don Juan Chuquichambe, curaca principal de Chiapa y Don García Chuquichambe indígena principal del mismo pueblo. El licenciado Martín de Moscoso y Buitrón fue incluso padrino de Felipe Chuquichambe, hijo de Don García Chuquichambe ${ }^{62}$. Además de otros indígenas y de sectores hispanos, los dos curas ayudantes de Camiña fueron padrinos de los hijos de Alonso Tala, quien fuera sacristán de la doctrina hacia 1681 y que estaba entre los que acreditaron el buen cometido de los pastores en 168163. Estos indicios ilustran la existencia de una práctica de parentesco espiritual entre curas e indígenas líderes de la doctrina, lo que desde una dimensión simbólica y del ritual católico da cuenta de la proximidad de la Iglesia al interior de las familias de la jerarquía comunitaria indígena a fines del siglo XVII.

El estudio de estos antecedentes sobre las acciones políticas indígenas y el contexto parroquial nos lleva a pensar que las autoridades andinas de la doctrina de Camiña no eran simplemente sujetos inocentes y fáciles de ser persuadidos para dar una determinada declaración hacia 1681. Por una parte, se muestran comprometidos y protagonistas de los rituales católicos estableciendo estrechas comunicaciones con el Obispo y sus curas. Esto no es incompatible con el interés de los eclesiásticos por conseguir y orientar unos testimonios que les fueran favorables. Como ha sostenido Burns (2010), detrás de la producción de la escritura o documentos públicos en el Perú Colonial, como los informes de servicio que estudiamos, solían subyacer pactos sobrentendidos entre los múltiples intervinientes que escapan del registro documental.

El testimonio acerca de la erradicación total de la idolatría que supuestamente habría ocurrido en la doctrina de Camiña demanda de todas maneras consideraciones adicionales. Como es sabido las dinámicas de cristianización indígena fueron mucho más complejas que el enfrentamiento entre la conversión y la resistencia, y por el contrario, los grupos andinos coloniales fueron protagonistas activos en las creencias y prácticas de la religiosidad local (Griffith 1998; Mills 1997). Basta revisar el conocimiento antropológico basado en registros etnográficos contemporáneos que demuestran las creativas reinterpretaciones del cristianismo por parte de los pueblos de la región (Martínez 1989; Van Kessel 1992a, 1992b). La pretendida eliminación de la idolatría puede reflejar entonces una tolerancia que los curas y autoridades tuvieron hacia el catolicismo andino hacia 1681, cuyos rituales autóctonos fueron vistos como supersticiones y no como peligrosas idolatrías.

Ciertamente este tipo de testimonio no puede desentenderse de las condiciones de su producción vinculadas a las carreras eclesiásticas. Evidencias de distintas diócesis del virreinato peruano conectan las acusaciones de idolatría y movimientos de revitalización de cultos nativos con las aspiraciones de ascenso en la jerarquía eclesiástica de los curas (Acosta 1987; Ramos 1992). En el caso del obispado de Arequipa, el clero fundó sus carreras eclesiásticas en demostrar obras pastorales distintas a la persecución de indios idólatras. Por ejemplo, en la construcción y mantenimiento de templos para lo que requerían conservar buenas relaciones con los caciques e indios principales (Marsilli 2004, 2014). Las sociedades andinas, por otro lado, participaron intencionadamente en estas relaciones de servicio ofreciendo una versión de su correcta evangelización ahorrándose un proceso de coerción que en otros lugares tuvo consecuencias negativas para los naturales y sus autoridades. Declarar extinguidas las idolatrías y supersticiones encerraría una alianza entre curas e indígenas en Camiña, así como posiblemente también un cambio significativo en la percepción oficial de lo que eran los cultos o costumbres aceptadas dentro del marco de la religiosidad católica andina hacia fines del siglo XVII, así como una nueva manera de entender su relación con el cristianismo de parte de los indígenas.

¿Qué sucedió con los curas ayudantes de la parroquia de Camiña durante los años posteriores a la realización de su informe de servicio de 1681 ? Simón Vernal Gutiérrez aparece hasta 1686 sirviendo en la doctrina y no tenemos hasta ahora más pistas sobre algún posible ascenso ${ }^{64}$. Un dato no menor es que hacia 1682 existen registros parroquiales de fray 
Gabriel Vernal de la orden franciscana en Chiapa y Mocha, quien como señalamos más arriba es uno de los hermanos eclesiásticos de Simón Vernal Gutiérrez $^{65}$. No debe ser coincidencia entonces que ambos sirvieran en la misma doctrina. Por su parte, Martín de Moscoso y Buitrón corrió distinta suerte, quizás porque al fin y al cabo contaba con contactos familiares con mayor influencia al interior de la Iglesia. En diciembre 1687, seis años después de estas declaraciones, este licenciado recibió en España finalmente una esperada noticia: su nombramiento como racionero del cabildo eclesiástico del Cusco. El nombramiento se fundaba en su idoneidad y calidad. Originalmente le habían proporcionado el mismo título en Arequipa, pero sucedió que antes la prebenda del Cusco fue declarada vacante. El excura ayudante de Camiña tenía plazo de dos años para tomar posesión de su puesto en el cabildo cusqueño. Según la instrucción, el obispo debía hacer colación y canónica institución de la ración aludida debiendo "acudir con todos los frutos y rentas proventas y emolumentos a ella anejos devidos y perteneçientes de todo bien" 66 . En la diócesis cusqueña fue también cura en la parroquia de Sicuani, ingresó al coro de penitenciarios, ejerció el Provisorato y falleció finalmente como Arcediano (Echeverría 1952 [1804]). Su ascenso obedecía a la exitosa combinación de la calidad de nobleza americana heredada por su familia, redes y amistades influyentes, obras piadosas y la supuesta eliminación de la idolatría de los indígenas de Camiña.

\section{Observaciones Finales}

La "Información sumaria de Testigos sobre el servicio del cura y vicario foráneo del curato de Camiña Don Martín de Moscoso y Buitrón ante el teniente de corregidor de la Provincia de Tarapacá don Francisco Gutierres de Escalante (1681)", junto a los otros documentos originales citados en el texto, nos permite reinterpretar esas fuentes en el sentido que más que reflejar una labor exitosa de evangelización que hubiese eliminado las prácticas andinas del cristianismo colonial en Camiña, nos habla más bien de un acuerdo entre las partes que garantizaba mejores relaciones para todos los involucrados dentro de las desiguales condiciones coloniales.
Desde las perspectivas de los doctrineros, las declaraciones de sus feligreses que se encontrarían completamente cristianizados y que eran ajenos a las prácticas idolátricas del pasado, las que habrían superado gracias a la dedicación de sus pastores, confirmaría por completo lo que esperaban que fuera escuchado por sus superiores en la perspectiva de alcanzar una nueva destinación más alta. Antecedente que se vería consolidado por la colaboración de las comunidades indígenas en la reconstrucción de sus iglesias. Por otra parte, su red de parientes criollos tendrían que sentirse satisfechos de esta posible promoción para sus perspectivas personales futuras, por el prestigio familiar y por las facilidades que se les consolidaban localmente para el uso de mano de obra para empresas agrícolas, mineras y de transporte que les podrían facilitar las autoridades indígenas aliadas a sus curas. Los criollos consolidaban así una posición de dominio simbólicamente respaldada por el pariente religioso.

En la perspectiva indígena, su participación en la Información, junto con apoyar a su cura, significaba obtener una carta de pureza de fe, ser reconocidos como cristianos intachables ante las autoridades eclesiásticas y con ello detener cualquiera posibilidad de iniciarse un juicio de extirpación de idolatrías que conllevaba la posibilidad de fuertes castigos, incluyendo acusaciones a los propios caciques e hilacatas. Implicaba, entonces, la confirmación de la estructura de autoridades indígenas y del sistema de cargos. Consolidaba la alianza con los indios del común y su cercanía con las autoridades religiosas oficiales los legitimaba, quizá tanto como a la vez mantener una resemantización creativa del cristianismo y de sus propias prácticas cúlticas como lo demuestran la pervivencia del catolicismo andino detectado por los antropólogos contemporáneos.

Agradecimientos: Agradecemos al Fondecyt Regular No 1071132 y al Fondecyt Postdoctoral $\mathrm{N}^{\circ} 3060120$. La versión final del trabajo se desarrolló en el Fondecyt $N^{\circ} 1130667$. Vaya nuestra gratitud a Simón Urbina por facilitar documentación complementaria proveniente del Archivo General de Indias. Agradecemos igualmente a los anónimos evaluadores de Chungara quienes nos han permitido mejorar la versión original. 


\section{Referencias Citadas}

Siglas

AAA Archivo Arzobispal de Arequipa

AGI Archivo General de Indias

AOI Archivo del Obispado de Iquique

AAA, Camiña, Legajo único. 1632. Visita del Pueblo de Camiña al Licenciado don diego gonçales buitrón año de mil y seis sientos y treynta y dos.

AGI, Lima 316, Propuesta al Obispado de Cusco para la División del Curacazgo de Tarapacá por el cura Francisco Churro de Aguilar y Marcos Valdelomar, 1571.

AGI, Lima 249, No 12, Informaciones: Antonio de Buitrón y Mújica.

AGI, Lima 249, Nº 13 Informaciones Diego Pérez de Vargas Machuca.

AGI, Lima, 250, $\mathrm{N}^{\circ}$ 16. Informaciones Esteban de Valencia.

AGI, Lima 264, No 7 (3). Oficio del Dean y Cabildo de la Santa Iglesia de Arequipa dirigida a su Majestad para que se le otorgue una prebenda al Licenciado Martín de Moscoso y Buitrón.

AGI, Lima $264 \mathrm{~N}^{\circ} 16$. Información de mérito de Simón Vernal Gutiérrez cura asistente de la Doctrina de Camiña.

AGI, Lima, 264, № 17 (1). Información sumaria de Testigos sobre el servicio del cura y vicario foráneo del curato de Camiña Don Martín de Moscoso y Buitrón ante el teniente de corregidor de la Provincia de Tarapacá don Francisco Gutierres de Escalante (1681).

AGI, Lima 264, No 17(4). Nombramiento de Visitador de la Provincia de Tarapacá en el Lizenciado Don Martin de Moscoso y Buitrón.

AGI, Lima 264 No 19. Información de mérito presentado por Thomas Vernal Gutiérrez, vecino de Arequipa, a favor de sus hijos que sirven a la iglesia.

AGI, Lima 529. Informe de los Sugetos benemeritos asi eclesiastico como seculares del Obispado de Arequipa.

AGI, Casa de la Contratación, 5450, N ${ }^{\circ} 39$. Expediente de información y licencia de pasajeros de indias de Martín de Moscoso y Buitrón, racionero de la Catedral del Cuzco.

AGI, Charcas 490, No 14. Mandamiento del Virrey del Perú, por el que se separa de la jurisdicción y corregimiento de Arica la antigua provincia de Tarapacá, erigiéndola en gobierno distinto e independiente y se señalan sus límites.

\section{Fuentes manuscritas}

Autos de la división de los obispados de Gvamanga y Areqvipa separados del Cuzco. Por nuestro Sanctissimo Padre Paulo Pappa V. A instancia de la Magestad Catholica del Rey Don Philippe III.

Constitvciones Synodales, del Obispado de Arequipa hechas, ordenadas por el Ilvstrissimo y Reuerendissimo Señor Doctor Don Antonio de Leon su Obispo, del Consejo de su Magestad en la Synodo Diocessana que celebro Año de 1684.

\section{Fuentes publicadas}

Acosta, A. 1982. Religiosos, doctrinas y excedente económico indígena en el Perú a comienzos del siglo XVII. Histórica, Vol. VI No 1:1-34.

Acosta, A. 1987. Estudio biográfico sobre Francisco de Ávila. En Ritos y Tradiciones de Huarochirí del Siglo XVII, editado por G. Taylor, pp. 551-616. Instituto de Estudios Peruanos, Instituto Francés de Estudios Andinos, Lima.

Álvarez, B. 1998 [1588]. De las Costumbres y Conversión de los Indios del Perú. Memorial a Felipe II, editado por M.C. Martín, J.J.R. Villarías y F. del Pino. Ediciones Polifemo, Madrid.

Barnadas, J. 1990. La iglesia católica en la Hispanoamérica colonial. En Historia de América Latina, Vol. 2 América Latina Colonial: Europa y América en los Siglos XVI, XVII, XVIII, editado por L. Bethell, pp. 185-207. Cambridge University Press, Editorial Crítica, Barcelona.

Bertonio, L. 1984 [1612]. Vocabulario de la Lengua Aymara. Centro de Estudios de la Realidad Económica y Social, Cochabamba.

Brading, D. 1991. Orbe Indiano. De la Monarquía Católica a la República Criolla, 1592-1867. Traducido por J.J. Utrilla. Fondo de Cultura Económica, México D.F.

Burns, K. 2010. Into the Archive: Writing and Power in Colonial Perú. Duke University Press, Durkham, London.

Castro, V. 2009. De Ídolos a Santos. Evangelización y Religión Andina en los Andes del Sur. Fondo de Publicaciones Americanistas, Universidad de Chile, Centro de Investigaciones Diego Barros Arana, Santiago.

Cateriano, M.A. 1908. Memorias de los Iltmos. Srs. Obispos de Arequipa Desde la Erección de esta Iglesia hasta Nuestras Días. Tipografía Quiróz, Arequipa.

Cordero Fernández, M.M. 2010. Las Visitas de Idolatrías. Diócesis de Lima. Siglo XVII. Tesis para optar al grado de Doctorado, Facultad de Historia, Geografía y Ciencias Políticas Pontificia Universidad Católica de Chile, Santiago.

Charles, J. 2010. Testimonios de coerción en las parroquias de indios: Perú, siglo XVII. En Los Indios ante los Foros de Justicia Religiosa en la Hispanoamérica Virreinal, editado por J.E. Traslosheros y A. de Zaballa Breascochea, pp. 111-126. Universidad Nacional Autónoma de México, México D.F.

Davies, K. 1984. Landowners of Colonial Peru. University of Texas Press, Austin.

Dean, C. 2002. Familiarizando el catolicismo en el Cusco colonial. En Incas e Indios Cristianos: Elites Indígenas e Identidades Cristianas en los Andes Coloniales, editado por J.J. Decoster, pp. 169-194. Centro Bartolomé de Las Casas / Kuraka / Instituto Francés de Estudios Andinos, Cusco.

Diez de Hurtado, A. 2005. Los sistemas de cargos religiosos y sus transformaciones. En Religiones Andinas, editado por M. Marzal, pp. 253-286. Editorial Trotta, Madrid.

Duviols, P. 1971. La Lutte contre les Religions Autochtones dans le Pérou Colonial L'Extirpation de L'Idolatrie entre 1532 et 1660. IFEA, Lima. 
Echeverría y Morales, EX. 1952 [1804]. Memorias de la Santa Iglesia de Arequipa. En Memorias para la Historia de Arequipa Tomo IV, editado por V. Barriga. Biblioteca Arequipa, Arequipa.

Elliott, J. 2009. Rey y patria en el Mundo Hispánico. En España, Europa y el Mundo de Ultramar [1500-1800], editado por J. Elliott. Traducido por M. Balcells. Editorial Taurus, Madrid.

Estenssoro, J. 2003. Del Paganismo a la Santidad. La Incorporación de los Indios del Perú al Catolicismo 1532-1750. UCP, IFEA, Lima.

Guevara Gil, A. y F. Salomon 1996. La Visita Personal de Indios: Ritual Político y la Creación del "Indio" en los Andes Coloniales. Instituto Riva-Agüero, Pontificia Universidad Católica del Perú, Lima.

Garrett, D. 2005. Shadows of Empire: The Indian Nobility of Cusco, 1750-1825. Cambridge University Press, Cambridge.

Griffiths, N.1998. La Cruz y la Serpiente: la Represión y el Surgimiento Religioso en el Perú Colonial. Traducido por C. Baliñas Pérez. Fondo Editorial Pontificia Universidad Católica del Perú, Lima.

Hidalgo, J. 2009. Corregidores Ilustrados en el Desierto de Arica, Tarapacá y Atacama 1760-1780. Academia Chilena de la Historia 118:91-55.

Hidalgo, J. 2011. Redes eclesiásticas, procesos de extirpación de idolatrías y cultos andinos coloniales en Atacama. Siglos XVII y XVIII. Estudios Atacameños Arqueología y Antropología Surandinas 42:113-152.

Hidalgo, J., V. Díaz y P. Cisternas 2014 [1985]. Cartas del obispo de Arequipa sobre los indios del corregimiento de Arica, 1620-1638. Cuatro documentos inéditos. En Historia Andina en Chile Vol. II Políticas Imperiales, Dinámicas Regionales y Sociedades Indígenas editado por J. Hidalgo, pp. 159-170. Editorial Universitaria, Santiago.

Irrigoyen, A. 2008. Un obispado para la familia: Francisco Verdín Molina, prelado de Guadalajara y Valladolid en la segunda mitad del siglo XVII. Historia Mexicana 58:557-594.

Jurado, C. 2014. Descendientes de los primeros. Las probanzas de méritos y servicios y la genealogía cacical. Audiencia de Charcas, 1574-1719. Revista de Indias 74:387-422.

Larson, B. 1988. Cochabamba, 1550-1900: Colonialism and Agrarian Transformation in Bolivia. Princeton University Press, Princeton.

Lavallé, B. 1982. Las doctrinas de indígenas como núcleos de explotación colonial (siglos XVI-XVII). Allpanchis 19:51-171.

Lockhart, J. y S. Schawartz 1983. Early Latin American: a History of Colonial Spanish America and Brazil. Cambridge University Press, Cambridge.

Lohman, G. 2001. El Corregidor de Indios en el Perú Bajo los Austrias. Fondo Editorial de la Pontificia Universidad Católica del Perú, Lima.

Lynch, J. 2012. Dios en el Nuevo Mundo. Una Historia Religiosa de América Latina. Traducido por A. Chaparro. Editorial Crítica, Barcelona.

Macleod, M.J. 1998. Self-promotion: The "Relaciones de Mérito y Servicios" and their historical and political interpretation. Colonial Latin American Historical Review 7:25-42.
Martínez, G. 1989. Espacio y Pensamiento I. Andes Meridionales. Editorial Hisbol, La Paz.

Martínez, M.E. 2014. Indigenous genealogies: lineage, history, and the colonial pact in central Mexico and Perú. En Indigenous Intellectuals. Knowledge, Power, and Colonial Culture in Mexico and the Andes, editado por G. Ramos y Y. Yannakakis, pp. 174-201. Duke University Press, Durkham, London.

Marsilli, M. 2002. God \& Evil in the Gardens of the Andean South: Mid-Colonial Rural Religion in the Diocese of Arequipa. Doctoral Dissertation, Department of History, Emory University, Atlanta.

Marsilli, M. 2004. Missing idolatry: Mid-colonial interactions between parish priests and indian in the diocese of Arequipa. Colonial Latin American Historical Review 4:399-421.

Marsilli, M. 2014. Hábitos Perniciosos: Religión Andina Colonial en la Diócesis de Arequipa (Siglos XVI al XVIII). DIBAM, Centro de Investigaciones Diego Barros Arana, CSIC Escuela de Estudios Hispano-Americanos, Santiago.

Marsilli, M. y P. Cisternas 2010. Los senderos de la idolatría: El viaje de Vázquez de Espinosa por los altos de Arica, 1618. Chungara Revista de Antropología Chilena 42:465-476.

Marzal, M. 1983. La Transformación Religiosa Peruana. Pontificia Universidad Católica del Perú, Lima.

Mills, Kenneth. 1997. Idolatry and Its Enemies: Colonial Andean Religion and Extirpation, 1640-1750. Princeton University Press, Princeton.

Núñez, L. y V. Castro 2011. ¡Caitunar, Caitunar!: Pervivencia de ritos de fertilidad prehispánica en la clandestinidad del Loa (Norte de Chile). Estudios Atacameños Arqueología y Antropología Surandinas 42:153-172.

O' Phelan, S. 1978. El Sur andino a fines del siglo XVIII: cacique o corregidor. Allpanchis 11:17-32.

Platt,T., T. Bouysse-Cassagne y O. Harris 2006. QaraqaraCharka. Mallku, Inka y Rey en la Provincia de Charcas (Siglos XV-XVII) Historia Antropológica de una Confederación Aymara. Instituto Francés de Estudios Andinos, Plural Editores, University of St Andrews, University of London, Inter American Foundation, Fundación Cultural del Banco Central de Bolivia, La Paz.

Ramos, G. 1992. Políticas eclesiásticas y extirpación de la idolatría: discursos y silencios en torno al Taqui Onkoy. Revista Andina 10:147-169.

Ramos, G. 2016. Pastoral Visitations: Spaces of Negotiations in Andean Indigenous Parishes. The Americas, The Academy of American Franciscan History 73:39-57.

Rostworowski, M. 1983. Estructuras Andinas del Poder. Ideología Religiosa y Política. Instituto de Estudios Peruanos, Lima.

Twinam, A. 2009. Vidas Públicas, Secretos Privados. Género, Honor, Sexualidad e Ilegitimidad en la Hispanoamérica Colonial. Traducido por C.I. Restrepo. Fondo de Cultura Económica, Buenos Aires.

Paz Soldán, M. 1878. Los Verdaderos Límites entre el Perú y Bolivia. Imprenta Liberal, Lima. 
Poma de Ayala, G. 1992 [1615/1616]. El Primer Nueva Coronica y Buen Gobierno. Editado por J. Murra y R. Adorno. Traducido por J.L. Urioste, Siglo XXI, México D.F.

Saignes, T. 1991. Lobos y ovejas: formación y desarrollo de los pueblos y comunidades en el sur andino (siglos XVI-XX). En Reproducción y Transformación de las Sociedades Andinas, Siglos XVI-XX, compilado por S. moreno y F. Salomon, pp. 91137. Editorial Abya-Yala-MLAL, Quito.

Taylor, W. 1996. Magistrates of the Sacred. Priests and Parishioners in Eighteenth-Century Mexico. Stanford University Press, Stanford.
Trelles, E. 1991. Lucas Martínez Vegazo: Funcionamiento de una Encomienda Peruana Inicial. Pontificia Universidad Católica del Perú, Lima.

Vial, J. 1984. Algunas referencias cronológicas sobre la historia de la iglesia en Arica, antes de la Guerra de 1879. Chungara 13:29-34.

Vargas Ugarte, R. 1951. Concilio Limenses (1551-1772), T. I. Arzobispado de Lima, Lima.

Walker, Ch. 2014. The Tupac Amaru Rebellion. The Belknap Press of Harvard University Press, Cambridge, London.

\section{Notas}

1 (Taylor 1996). Si bien el ciclo borbónico implicó un mayor dominio sobre la jerarquía eclesiástica y el clero, se ha matizado la disminución del poder de la Iglesia en la segunda mitad del siglo XVIII destacando por ejemplo la labor de Obispos y párrocos en su contribución a la derrota de la rebelión de Túpac Amaru (Walker 2014).

2 Los casos de idolatría nativa colonial en los territorios desérticos de la vertiente occidental de los Andes han presentado valiosos estudios. Tenemos el trabajo clásico de Castro (2009) relativo a la extirpación de idolatría en Atacama; Hidalgo (2011) y Núñez y Castro (2011) en la misma área con nuevos documentos. Hidalgo, Díaz y Cisternas (2014 [1985]) sobre Arica y Tarapacá (incluido Pica), y Marsilli y Cisternas (2010) sobre la actividad extirpadora de Antonio Vázquez de Espinoza en los Altos de Arica. Marsilli (2002) y Marsilli (2014) sobre el Obispado de Arequipa y la relación de carreras eclesiásticas con denuncias por idolatría indígena.

3 El escenario social y étnico es complejo para la zona de Tarapacá. Existen evidencias que indicarían la presencia del Puquina en la zona de Arica, que incluso alcanzaría hasta Iquique. Por otra parte, existen referencias tardías como la del Intendente Antonio Álvarez y Jiménez quien señala que en Tarapacá se hablaba el quechua. No obstante, las evidencias de los antropólogos contemporáneos en Arica y Tarapacá clasifican a esta población de habla aimara. Para una visión sumaria del mapa étnico pre-Hispánico en la zona véase Marsilli (2014:25-41). En tiempos coloniales las fugas de los pueblos de origen de los tributarios y su instalación como forasteros en otros lugares hizo que desde fines del siglo XVI nos encontremos con comunidades o pueblos pluriétnicos.

4 En las cuentas de la encomienda de Lucas Martínez Vegazo constaba que el encomendero costeaba el diezmo y salario en metálico para un sacerdote y proveía cera y vino para el culto (Trelles 1991:234-239).

5 Archivo General de Indias (en adelante, AGI) Lima 316, Propuesta al Obispado de Cusco para la División del Curacazgo de Tarapacá por el cura Francisco Churro de Aguilar y Marcos Valdelomar, 1571. La propuesta no contemplaba a caseríos y pueblos ubicados en la puna, tal como lo comprobaría algunos años después Bartolomé Álvarez al visitar el pueblo de Isluga, que se encontraba en una ambigua frontera entre el Obispado de Charcas y el de Cusco, por lo que no disponía de ningún doctrinero (Álvarez, 1998 [1588], 728: pp. 400).

6 AGI, Charcas 490, $\mathrm{N}^{\circ} 14$. Mandamiento del Virrey del Perú, por el que se separa de la jurisdicción y corregimiento de Arica la antigua provincia de Tarapacá, erigiéndola en gobierno distinto e independiente y se señalan sus límites. Lima, 29 de mayo, 1768.

7 La cita original describe a estos pueblos como "Cabina, Zibaya, Usa, Gama, Chiapa, Zotoca y Estagama”. Autos de la división de los obispados de Gvamanga y Areqvipa separados del Cuzco. Por nuestro Sanctissimo Padre Paulo Pappa V. A instancia de la Magestad Catholica del Rey Don Philippe III. Nuestro Señor, pp. 11. Visto en John Carter Library Peru Collections.

8 Archivo Arzobispal de Arequipa (en adelante, AAA), Legajo único 1632. Visita del Pueblo de Camiña al Licenciado don Diego Gonçales Buitrón año de mil y seis sientos y treynta $\mathrm{y}$ dos.

9 AGI, Lima, 264, N 17 (1). Información sumaria de Testigos sobre el servicio del cura y vicario foráneo del curato de Camiña Don Martín de Moscoso y Buitrón ante el teniente de corregidor de la Provincia de Tarapacá don Francisco Gutierres de Escalante (1681).

10 De acuerdo con los datos contenidos en los libros parroquiales Juan de Buitrón y Muxica comenzó a servir en la doctrina por el año 1653. En ese año aparece realizando bautismos en el pueblo de Mocha. Archivo del Obispado de Iquique (en adelante, AOI), San Lorenzo de Tarapacá, Bautismo y Matrimonios, 1652-1699, s/f. Mientras que hacia 1687, ya con varios años padeciendo el mal de la gota, siguió conservando el título de cura propietario y vicario. En una partida de julio de aquel año realizada por fray Gabriel Vernal se lee "...bautisse pusse olio y crisma a Bentura Coama; por Comission, y authoridad del Señor Vicario Don Juan de Butron y Muxica, cura propietario de este pueblo de Camiña y sus anejos" AOI, Santo Tomás de Camiña, Registros de Bautismos, 1653-1695, f.113v, f.66v.

11 AGI, Lima 529. Informe de los Sugetos benemeritos asi eclesiastico como seculares del Obispado de Arequipa.

12 Estas funciones quedaron establecidas para el caso del Obispado de Arequipa en las Constituciones Sinodales de 1684. Constitvciones Synodales, del Obispado de Arequipa. Hecha, ordenadas por el Ilvstrissimo y Reverendissimo Señor Doctor Don Antonio de Leon su Obispo, de Consejo de su 
Magestad en la Synodo Diocessana que celebro Año de 1684, Título Primero De Summa Trinitate, Fide Catholica, Título Segundo De officcio Vicario, Cap. 1, Del oficio de Vicario Foráneo, pp. 97. Visto en John Carter Library, Perú Collections.

13 Entre 1628 y 1632 había servido como cura propietario de Camiña Diego González Buitrón. Archivo Arzobispal de Arequipa, Camiña, Legajo único, 1632.

14 AGI, Lima 264, No 17. Información de mérito del Licenciado Martín de Moscoso y Buitrón cura asistente de la Doctrina de Camiña.

15 AGI, Lima 264, No 17. Información de mérito del Licenciado Martín de Moscoso y Buitrón cura asistente de la Doctrina de Camiña; AGI, Lima 249, Nº 12, Informaciones: Antonio de Buitrón y Mújica.

16 AGI, Lima 264, Nº 17. Información de mérito del Licenciado Martín de Moscoso y Buitrón cura asistente de la Doctrina de Camiña. El capitán Gómez de León estuvo bajo el mando de Pedro de Alvarado y posteriormente de Francisco Pizarro. Falleció en la batalla de Guarina en el marco de la rebelión de los Pizarros. Fue recordado por primera vez en 1581 dado que su hijo Antonio Gómez de Buitrón necesitaba ayuda del rey luego que la población de indios yungas de su encomienda heredada en Camaná y Maxes habían disminuido notablemente. Entre los testigos que apoyaron a Antonio Gómez de Buitrón en esa oportunidad se hallaban actores claves en la historia andina como García Diez de San Miguel. En 1677 fue evocado por Diego Moscoso y Buitrón, hermano del cura ayudante de Camiña, quien estaba interesado en elaborar una información para dejar memoria perpetua de los servicios y méritos pasados y presentes de la familia.

17 AGI, Lima 264 No 17, Información de mérito del Licenciado Martín de Moscoso y Buitrón cura asistente de la Doctrina de Camiña, f.54v. A diferencia de esta fuente del siglo XVII, Echeverría (1952 [1804]:259) consigna que por el contrario José Moscoso y Buitrón estudió en el Colegio de San Bernardo del Cuzco.

18 Sabemos que la educación adquirida por curas doctrineros era un factor fundamental en sus carreras eclesiásticas. La reconstrucción biográfica de la carrera promedio de los "licenciados" en el Obispado de Arequipa, por ejemplo, indica que estos curas inicialmente pasaban un promedio de 7,5 años sirviendo en parroquias relativamente alejadas de Arequipa, como Arica o Tarapacá. Luego lograban con éxito una promoción a parroquias vecinas al centro del Obispado, como las del valle del Collca, donde permanecían un promedio de 9,2 años. Finalmente, luego de todo este tiempo, los licenciados finalmente podían postular a una promoción al Cabildo Eclesiástico. Véase (Marsilli 2014:76-77).

19 Esto fue señalado en su informe de servicio. No obstante, la primera referencia de su presencia que hemos localizado en los libros parroquiales se remonta a 1671 donde se hallaba oficiando bautismos en el pueblo de Mocha. AOI, San Lorenzo de Tarapacá, 1652-1699, f.12v.

20 Sobre estos dos prebendados arequipeños consúltese: AGI, Lima, 250, No 16. Estevan de Valencia sacristán preocupado por la Catedral de Arequipa; y AGI, Lima 249, No 13 Informaciones Diego Pérez de Vargas Machucha, Juez Visitador general de Idolatría.
21 AGI, Lima 249, Nº 12. Informaciones: Antonio de Buitrón y Mújica.

22 AGI, Lima 264, No 17(4). Nombramiento de Visitador de la Provincia de Tarapacá en el Lizenciado Don Martin de Moscoso y Butron.

23 AGI, Lima 529. Informe de los Sugetos benemeritos asi eclesiastico como seculares del Obispado de Arequipa, f.4r.

24 La información más temprana que hemos podido hallar en los libros parroquiales del Obispado de Iquique sobre Simón Vernal Gutiérrez corresponde a julio de 1666 donde bautiza a personas originarias de ayllus y pueblos de Sotoca, Chiapa, Camiña y Pica. Ver AOI, San Lorenzo de Tarapacá, 1652-1699, s/f. Esto significa que llevaba en realidad 15 años sirviendo, resultando entonces peculiar que en una relación cuyo objetivo era destacar el desempeño de un funcionario, este obviara contabilizar con mayor precisión 3-4 años que acumulaba hacia 1681. Quizás Simón Vernal Gutiérrez estaba contabilizando los años desde que gozó de nombramiento como cura ayudante de Camiña, designación recibida primero por el Obispo fray Juan de Almoguera debida a la enfermedad del cura propietario Juan de Buitrón y Muxica, y que posteriormente fue refrendado por el Obispo Antonio de León. AGI, Lima 264 № 16. Información de mérito de Simón Vernal Gutiérrez cura asistente de la Doctrina de Camiña, f.4r. Esto en el caso que el nombramiento haya ocurrido algunos años después de 1666.

25 AGI, Lima $264 \mathrm{~N}^{\circ} 19$. Información de mérito presentado por Thomas Vernal Gutiérrez, vecino de Arequipa, a favor de sus hijos que sirven a la iglesia.

26 AGI, Lima, 264, No 17. Información de mérito del Licenciado Martín de Moscoso y Buitrón cura asistente de la Doctrina de Camiña, f.4r.

27 AGI, Lima 264 N N $^{\text {16 }}$. Información de mérito de Simón Vernal Gutiérrez cura asistente de la Doctrina de Camiña, f.2r.-f.2v.

28 AGI, Lima 264, № 7 (3). Oficio del Deán y Cabildo de la Santa Iglesia de Arequipa dirigida a su Majestad para que se le otorgue una prebenda al Licenciado Martín de Moscoso y Buitrón. 4 de julio de 1681. Agradecemos al arqueólogo Simón Urbina por facilitar este documento.

29 AGI, Lima $264 \mathrm{~N}^{\circ} 19$. Información de mérito presentado por Thomas Vernal Gutiérrez, vecino de Arequipa, a favor de sus hijos que sirven a la iglesia. 4 de julio de 1681 .

30 Archivo General de Indias, Lima 264 N ${ }^{\circ}$ 17. Información de mérito del Licenciado Martín de Moscoso y Buitrón cura asistente de la Doctrina de Camiña.

31 Para el siglo XVIII es posible de identificar en Tarapacá estrechas relaciones de parentesco entre autoridades civiles y eclesiásticas, así como figuras destacadas de los sectores económicos, mineros y comerciales (Hidalgo 2009).

32 Un conjunto de visitas realizadas en 22 parroquias indígenas de la Diócesis de Arequipa entre 1631 y 1719 indica que solo un cura falló la inspección. El cuerpo de visitas indica que de 96 testigos indios, solo 15 eran indios del común. El resto eran caciques principales o secundarios, alcaldes, o fiscales. Marsilli (2004:413).

33 AAA, Camiña, Legajo único, 1632.

34 Diversos autores han registrado la existencia en tiempos prehispánicos de organizaciones políticas duales, es decir, con dos mitades encabezadas cada una por un cacique (Matienzo; Garci Diez de San Miguel y otros). En tiempos coloniales 
la autoridad española enfatizó el papel del curaca de la mitad superior otorgando al otro el apelativo de "segunda persona", Rostworowski (1983). Mientras que los hilacatas, de voz aymara, eran otros "mandones" subordinados a los caciques principales que según los registros podían poseer un número específico de indios bajo su dominio. Ver nota 37.

35 En cada pueblo de reducción que pasara los cien habitantes debía existir dos o tres cantores y un sacristán a cargo de los ornamentos y la limpieza de la iglesia, ellos estaban libres de tasas y cualquier servicio personal, según ley de 1618. Recopilación de Leyes de Indias, Libro Sexto, Título Tercero. De las Reducciones y Pueblos de Indios, Ley VI.

36 Algunos nombres de los indios principales de estos pueblos difirieron en las informaciones de Martín de Moscoso y Buitrón, y Simón Vernal Gutiérrez. Sobre los sistemas de cargo en el espacio andino consúltese Diez de Hurtado (2005).

37 Hilacata: principal del ayllu (Bertonio 1984 [1612]:133). Cabe mencionar, no obstante, que en el registro se privilegió la utilización de la voz quechua, más difundida, de curaca para denotar a los jefes principales en vez de emplear algún vocablo aymara de autoridad como mallku.

38 AGI, Lima $264 \mathrm{~N}^{\circ} 17$ (1). Información de mérito del Licenciado Martín de Moscoso y Buitrón cura asistente de la Doctrina de Camiña, f.10r.

39 AGI, Lima $264 \mathrm{~N}^{\circ} 17$ (1). Información de mérito del Licenciado Martín de Moscoso y Buitrón cura asistente de la Doctrina de Camiña, f.8r. Además de las evidencias en los libros parroquiales de Camiña que revisaremos más adelante, el grado de interiorización e importancia que los indígenas tenían por la administración de los sacramentos quedó demostrada durante la rebelión de Túpac Amaru. La apropiación de la doctrina cristiana por parte de los indígenas se expresa muy bien en la respuesta de este líder rebelde a una solicitud de eliminar a los curas, la cual rechazaba señalando que si así fuera hecho ya nadie podía absolverlos en la hora de la muerte (Walker 2014:66).

40 AGI, Lima $264 \mathrm{~N}^{\circ}$ 16. Información de mérito de Simón Vernal Gutiérrez cura asistente de la Doctrina de Camiña, f.10v.

41 AGI, Lima $264 \mathrm{~N}^{\circ}$ 16. Información de mérito de Simón Vernal Gutiérrez cura asistente de la Doctrina de Camiña, f.9r.

42 AGI, Lima $264 \mathrm{~N}^{\circ} 17$ (1). Información de mérito del Licenciado Martín de Moscoso y Buitrón cura asistente de la Doctrina de Camiña, f.8r.

43 Disímil a la visión por ejemplo de Guamán Poma de Ayala (1980 [1615/1616]:550) que advierte en estos azotes un flagelo denunciable quien calificaba a los sacerdotes como verdugos.

44 En su visita de 1636 al partido de Arica, el Obispo Pedro de Villagómez distinguía a los doctrineros que asistían a los enfermos y les llevaban medicinas a diferencia de los corregidores que no pagaba el tomín para el hospital y dejaban morir solos a los indios en sus pueblos (Hidalgo et al. 2014 [1985]).

45 AAA, Camiña, Legajo Único 1632.

46 AGI, Lima 232, No 5. Informaciones Pedro de Porrasdana, 1637.

47 Griffiths (1998) ha llamado la atención que los procesos por idolatría continuaron incluso en el siglo XVIII, aunque distingue dos períodos de actividad intensa. El primero entre 1609 y 1622 , y el segundo entre 1649 y 1670 . Mills (1997), en cambio, anticipó en su extenso trabajo sobre extirpación de idolatrías en los Andes Centrales la idea que los cultos nativos sobrevivieron al catolicismo dominante precisamente porque los nativos los adaptaron al discurso y al ejercicio de las prácticas represivas coloniales. Para este autor, ortodoxia hispana y desviaciones religiosas indígenas son parte de un juego de opuestos que se desarrolló durante todo el período colonial.

48 Constitvciones Synodales, del Obispado de Arequipa. Hecha, ordenadas por el Ilvstrissimo y Reverendissimo Señor Doctor Don Antonio de Leon su Obispo, de Consejo de su Magestad en la Synodo Diocessana qve celebro Año de 1684, Título Primero De Summa Trinitate, Fide Catholica, Título III De Summa Trinitate Fide Catholica, Capítulo III, Cuidado que deben tener los curas para la extirpación de la Idolatría de los Indios. Visto en John Carter Library Peru Collections.

49 Cateriano (1908:75).

50 AGI, Lima 264, N 17 (4). Nombramiento de Visitador de la Provincia de Tarapacá en el Lizenciado Don Martín de Moscoso y Butron, 2 de octubre de 1680, f.1r.

51 AGI, Lima $264 \mathrm{~N}^{\circ} 17$ (1). Información de mérito del Licenciado Martín de Moscoso y Buitrón cura asistente de la Doctrina de Camiña, f.6r-f.6v.

52 AGI, Lima $264 \mathrm{~N}^{\circ} 17$ (1). Información de mérito del Licenciado Martín de Moscoso y Buitrón cura asistente de la Doctrina de Camiña, f.12r.

53 El origen de las relaciones o probanzas de méritos y servicios se hallaba en la tradición ibérica medieval de la "mutua obligación" entre el monarca y sus vasallos (Macleod 1998).

54 A nuestro juicio, en este caso, no toda la información proporcionada por los indígenas puede ser reducida únicamente a un preestablecido discurso, y varias de las informaciones por ejemplo las que sugieren pestes y sequías pueden ser comprobadas por otra documentación referida al sur andes y Tarapacá. La información de las duras y frecuentes pestes se pueden contrastar con la mortandad que afectó a distintos grupos etarios de algunos anexos de la doctrina durante la época en que servían Martín de Moscoso y Buitrón, y Simón Bernal Gutiérrez. Ver por ejemplo AOI, Parroquia de Chiapa, Bautismos, confirmaciones, matrimonios y defunciones 1670-1718.

55 AOI, San Lorenzo de Tarapacá, Bautismos y matrimonios 1652-1699, f.5r.-f.9r.

56 Los registros de matrimonios no especifican de qué pueblo o anexo corresponden los hilacatas y sacristanes, aunque la mayoría señala que se desarrollaron en Mocha, pero esto no quiere decir necesariamente que estas autoridades pertenecían a este pueblo. El sacristán Balthasar Tinta presente en estos matrimonios coincide con el nombre de uno de los indios principales de Sibaya en la relación de servicio de Martín de Moscoso y Buitrón de 1681. Lo mismo sucede con el sacristán Juan Jachura que coincide como unos de los indios principales del pueblo de Sotoca de 1681. Es probable que se traten de las mismas personas, pues el calificativo de indio principal recaía generalmente en aquellos miembros de las comunidades que habían ostentando cargos comunitarios de orden religioso y/o político.

57 AOI, Parroquia de Chiapa, Bautismos, confirmaciones, matrimonios y defunciones 1670-1718, s/f. 
58 Tal vez fue durante esta visita cuando el Obispo constató lo que juzgó como señas de persistencia de cultos idolátricos entre los indígenas de la doctrina, pues como mencionamos anteriormente solo un mes más tarde de acabada esta inspección nombró a Martín de Moscoso y Buitrón como visitador de idolatría.

59 En su visita, Antonio de León ordenó a los curas que siguieran fielmente el Manual Romano para el registro de bautismo anotando con claridad y precisión el día de nacimiento del bautizado, nombres de padres y padrinos, y las firmas de fe. $\mathrm{Si}$ acaso quien firmaba no era el cura o bien el sacramento era realizado por algunos de los tenientes del cura propietario, se debía consignar la firma de quien bautizó y la firma de quien daba la licencia. Algunos libros parroquiales de Camiña no fueron llevados con esa precisión. AOI, Santo Tomás de Camiña, Bautismos 1653-1695, f.35r.

60 El I Concilio Limense (1551-1552) sostuvo que principalmente se debían administrar los sacramentos de bautismo, penitencia y matrimonio a los indios. Los otros sacramentos estaban reservados a aquellos que estuvieran más instruidos y arraigados en la fe. De todas maneras, los prelados, es decir el alto clero, podía administrar la confirmación a los indios si acaso lo vieran conveniente. En cambio, el II Concilio Limense (1567-1568) ordenó que los Obispos administraran la confirmación a los indios que estuvieran previamente bautizados y que les fueran costeados los enseres del culto como velas y vendas por considerarlos como indios pobres. El decisivo III Concilio
Limense (1582-1583) refrendó lo dispuesto anteriormente, ordenando que los obispos proveyeran los materiales para la confirmación y prohibiendo que se les recibiera dinero por parte de los indios. Ver Vargas Ugarte (1951). En teoría, la confirmación de cientos de indígenas de la Doctrina de Camiña sugiere que el Obispo los consideraba hacia 1680 como cristianos que conocían a cabalidad la doctrina y misterios de la fe.

61 De acuerdo con el código social hispanoamericano colonial, el título de "Don" implicaba el reconocimiento de rango social y entre otros aspectos, que la persona poseía una descendencia legítima y que podía ejercer cargos públicos y de orden religioso. Twinam (2009) discute cómo estos títulos fueron motivo de conflictos entre las elites locales hispanoamericanas.

62 AOI, Santo Tomás de Camiña Bautismos 1653-1695, f.83v.

63 Se trataba de Lorenzo Choquela, cuyo padrino fue Martín de Moscoso y Buitrón, y de Juana Pirina cuyo padrino fue Simón Vernal Gutiérrez. AOI, Santo Tomás de Camiña Bautismos 1653-1695, f.84r.

64 AOI, San Lorenzo de Tarapacá, Bautismos y matrimonios 1652-1699, s/f.

65 AOI, Parroquia de Chiapa, Bautismos, confirmaciones, matrimonios y defunciones de Chiapa, 1670-1718, s/f.

66 AGI, Casa de la Contratación, 5450, N 39 , f.4v. Posteriormente Martín de Moscoso se encontrará en Sevilla gestionando con las autoridades de la Casa de la Contratación su retorno a tierras americanas. 